(C) 2018 by A.M. Barszcz. This is an open access article distributed under the Creative Commons Attribution-NonCommercial-NoDerivs license (http://creativecommons.org/licenses/by-nc-nd/3.0/)

\title{
VALIDATION OF CSD ADVANCED ANALYSIS OF BRACED FRAME RESPONSES USING SUBFRAME EXPERIMENTAL INVESTIGATIONS
}

\begin{abstract}
A. M. BARSZCZ ${ }^{1}$
This paper deals with a Continuous Stiffness Degradation (CSD) version of advanced analysis of braced steel framing. It is based on the gradual stiffness degradation concept of frame and truss members. A novelty of the approach presented herein is related to the introduction of the bracing member response in the whole range of its behaviour in tension and compression, including the post-limit range. The validation of the proposed advanced analysis is performed for braced framework with rolled angle section braces. The validation of the brace force-deformation model has been presented in the author's earlier publication. The basis for the presented CSD advanced analysis is briefly summarized and its difference with regard to the Refined Plastic Hinge (RPH) version of advanced analysis is emphasized. Experimental investigations dealing with tests on portal braced sub-frame specimens are referred to briefly. Results of the experimental investigations are presented in the form of a frame global response and they are used for the validation of the developed computational model.
\end{abstract}

Keywords: steel framework, braced frame, angle brace, post-limit brace behaviour, CSD advanced analysis, validation of computational model

\section{INTRODUCTION}

Research concerning skeletal steel framing has been conducted for many years, starting from analysis and design of plane rigid joint frames, followed by space framing, and recently extended for semi-rigid steelworks, both planar and spatial. Firstly, the interest of research investigations was focused on the elastic range of structure behaviour, while later investigations were directed towards different aspects of the inelastic behaviour with regard to the second order effects [1]. In the earlier stage, practical methods of the analysis and design of steel rigid frames concerned the plastic hingemethod because of its simplicity and acceptable accuracy of predicting the ultimate limit state despite the fact that the displacement predictions would have generally been much less accurate than the resistance ones [2]. More recent investigations have proven that the plastic hinge method may - in the cases of some frames - overestimate resistance, leading to an unsafe inelastic design;

\footnotetext{
${ }^{1}$ PhD., Eng., Warsaw University of Technology, Faculty of Civil Engineering, Al. Armii Ludowej 16, 00-637 Warsaw, Poland, e-mail: a.barszcz@il.pw.edu.pl
} 
especially true when hinges form in columns [3]. Research interest then became focused on the effects of distributed plasticity and its inclusion in practical methods of structural analysis and design [4]. Refined plastic hinge methods were developed for practical inelastic design since they combine the simplicity of the conventional plastic hinge method and allow for the effect of distributed plasticity (inelastic stress redistribution in the section and spread of plastic zones along the member length). When cost effectiveness of steel construction became a dominating factor, semi-rigid framing started to gain popularity. A great burden of research was directed towards theoretical and experimental investigations of joint behaviours and the development of suitable modelling techniques for the analytical description of joint moment-rotation characteristics. An overview of joint behaviour research has been summarized in [5]. Classical methods of analysis were then expanded to take into account joint flexibility for limit state predictions [6,7]. Since refined plastic hinge methods of analysis take into account geometric nonlinearity and the influence of imperfections and joint deformability, they are referred to as advanced methods of analysis. Chen and Kim [8] presented an advanced method of analysis using refined plastic hinges and Lagrangian corotational approach. Such method can be used for direct design of steel plane frames, both sway and braced nonsway. The effect of the axial force on the inelastic behaviour of members in both the frame moment resisting subsystem and the truss bracing subsystem is considered. It is represented by the values of tangent stiffness $\left(E_{\mathrm{T}} I\right)$ for the effect of axial force on the stiffness of momentresisting members and tangent stiffness $\left(E_{\mathrm{T}} A\right)$ for the effect of axial force on the stiffness of axialforce-resisting members. These two stiffness measures (when related to their initial values of $E I$ and $E A$, respectively) constitute the degradation function reproducing the buckling curve via the Shanley bifurcation tangent buckling theory. Single LRFD (Load and Resistance Factor Design) and CRC (Column Research Council) buckling curves were adopted by Chen and Kim [8] and an explicit distinction between elastic and inelastic buckling regions was used with a threshold point of $\alpha_{\mathrm{N}}=0,5$ between them in the latter. In order to account for stiffness degradation under the combination of the force state components, axial force $N_{\mathrm{Ed}}$ and bending moment $M_{\mathrm{Ed}}$, the twosurface degradation model was adopted in relation to frame member ends. Since a gradual reduction of member initial stiffness refers only to member ends, the method is fully effective for frames loaded only at nodes. In cases of members with span loads, such members need to be subdivided into several frame sub-elements with nodes placed at the points of concentrated loads and maximum moments in order to properly account for the $P-\delta$ and $P-\Delta$ effects. The effects of plastic deformation on flexural stiffness reduction is utilized through force state parameter $\alpha_{\mathrm{M}-\mathrm{N}}$ at each end of the member or its subdivided elements $\left(\alpha_{\mathrm{M}, \mathrm{i}-\mathrm{N}}\right.$ and $\alpha_{\mathrm{M}, \mathrm{k}-\mathrm{N}}$ for the ends "i" and " $\mathrm{k}$ ") thereby replacing 
parameter $\alpha_{\mathrm{N}}$ in the evaluation of the member stiffness degradation function. The elastic limit curve for which the stiffness degradation function equals to unity is therefore the scaled plastic limit curve for which the stiffness degradation function equals to zero. A scaling factor of 0,5 was adopted for the elastic limit curve.

Conventional models for bracing members assume that the force redistribution process in braced frames takes place up to the buckling resistance attainment for the first member of the bracing system (lower-bound estimate of frame resistance). The upper-bound estimate of frame resistance is evaluated when, under loads increased above the level corresponding to the attainment of the brace buckling resistance, the buckling resistance is maintained in buckled members throughout the further force redistribution process. Both approaches have to be recognized as approximate since the bracing member takes part in the force redistribution process in the post-limit range with a negative stiffness. This means that members with a positive stiffness need to take up not only an additional load increment, but also the incremental drop of the axial force of brace members overpassing the deformation level which corresponds to their buckling resistance. Over the last two decades, research on direct design methods based on advanced analysis of semi-continuous steel framing has been taking place in Poland, starting in [9] with the Chen-Kim RPH version of advanced analysis which then evolved towards the CSD version [10] of which the author of this paper has been the principal investigator. The review of different analysis methods for steel framework design was presented in [11,12], including those concerning advanced analysis. The major differences between CSD advanced analysis and its Chen-Kim RPH counterpart arose from the application of: a) the continuous stiffness degradation concept used for both frame and truss members treated as imperfect elements without an explicit predefinition of the boundary threshold between the elastic and inelastic ranges of member behaviour, b) the definition of force state parameter $\alpha_{\mathrm{M}-\mathrm{N}}$ as the ratio of actual end section moment $M_{\mathrm{Ed}, \mathrm{i}}$ or $M_{\mathrm{Ed}, \mathrm{k}}$ to $M_{\mathrm{N}, \mathrm{Rk}}$ as the plastic section resistance reduced with regard to actual axial force $N_{\mathrm{Ed}}$ in the member, c) the utilization of a more precise force-deformation characteristic then those used earlier for the reproduction of the real behaviour of brace elements in the form of an equivalent truss member (i.e. including both pre-limit and post-limit ranges of brace behaviour).

In recent years, the nonlinear behaviour of planar steel frames with semi-rigid connections with the effects of material inelasticity not taken into account has been an ongoing matter of research interest $[13,14]$. Greater interest, however, is devoted to the inelastic range of behaviour of semicontinuous framework taking into account both the time-dependent structure response [15] and the response under a monotonically increased load [16]. Investigations presented in the latter paper deal 
with displacement-based finite element second-order distributed plasticity analysis of planar steel frames with semi-rigid beam-to-column joints. Coupling effects leading to nonlinear behaviour as well as geometric and material imperfections are investigated. The results of the nonlinear inelastic response predicted via GMNIA (Geometrically and Materially Nonlinear Imperfect structure Analysis) through the proposed advanced analysis are compared with those of previous studies. Yet another area of major international research interest is related to advanced analysis of composite steel-concrete framing which is not mentioned in this paper. Various research-to-practice aspects relating to methods of the direct design of steel and composite structures have recently been presented in [17].

This paper presents the author's contribution to the development of the theoretical CSD advanced method of analysis in relation to the authentic behaviour of steel braced framing. The basis of this method is described with an emphasis on its advantage over the conventional RPH approach. The validated angle brace analytical model used in this paper is presented in [18], describing the equilibrium path in the form of a dimensionless force-deformation characteristic (stress-strain relationship with softening). This model is constructed for a hypothetically perfect element which reproduces the behaviour of real imperfect braces with different end connections. Two different boundary conditions of equal leg angle connections, typical for engineering practices, are dealt with; braces with welded fork-type mono-eccentric connections and braces with bolted lap-throughone-leg bi-eccentric connections. The principal purpose of this paper is to validate the previously developed CSD advanced analysis using the results of the global response of braced portal subframes obtained during the experimental investigations presented in [19].

\section{CSD ADVANCED ANALYSIS OF BRACED PLANAR FRAMEWORK}

\subsection{MODELLING OF MOMENT-RESISTING SUBSTRUCTURE BEAM-COLUMN ELEMENT}

The formulation of basic CSD advanced analysis equilibrium equations follows that of RPH analysis [8] where the assumption of concentrated plasticity (formation of plastic hinges at member ends) is replaced by an approximate modelling of distributed plasticity (formation of plastic zones from member ends along their length). Such advanced analysis takes into account all the most important factors affecting the performance of real steel framework. First, it is of the GMNIA type, i.e. it is able to reproduce the nonlinear equilibrium path of real load-bearing skeletal structures. This means that at least effects like geometrical and material member and structure nonlinearities, 
effects of geometrical and material imperfections, as well as nonlinear joint characteristics are considered in the global response analysis. As a result, a design approach based on such analysis is able to trace the structure's equilibrium path evaluating the limit point under specified design load combinations.

Let us consider framework composed of class 1 section members used for moment-resisting substructures and compact section members used for axial force-resisting bracing substructures. The Cartesian corotational LCS (Local Coordinate System), with $x$ being the member axis coordinate originating at the member "ip" end, is introduced. The following incremental relationship holds true for the super-element of a moment-resisting substructure consisting of a frame element bent about the principal axis considered together with zero-length end joint rotational springs:

$$
\left\{\Delta Q_{\mathrm{Ed}}\right\}=\left[k_{\mathrm{Tf}}\right]\left\{\Delta q_{\mathrm{Ed}}\right\}
$$

where:

$\left\{\Delta Q_{\mathrm{Ed}}\right\}$ - the incremental generalized nodal force vector, $\left\{\Delta q_{\mathrm{Ed}}\right\}$ - the incremental generalized nodal displacement vector, $\left[k_{\mathrm{Tf}}\right]$ - the frame element tangent stiffness matrix in LCC given by:

$$
\begin{gathered}
\left\{\Delta Q_{\mathrm{Ed}}\right\}=\left\{\begin{array}{c}
\Delta M_{\mathrm{Ed}, \mathrm{i}} \\
\Delta M_{\mathrm{Ed}, \mathrm{k}} \\
\Delta N_{\mathrm{Ed}}
\end{array}\right\} \\
{\left[k_{\mathrm{Tf}}\right]=\left[\begin{array}{cc}
\frac{(E I)_{T f}}{L}\left[k_{\mathrm{T \theta}}\right] & \{0\} \\
\text { symm. } & (E A)_{T f}
\end{array}\right]} \\
\left\{\Delta q_{\mathrm{Ed}}\right\}=\left\{\begin{array}{c}
\Delta \theta_{\mathrm{Ed}, \mathrm{i}} \\
\Delta \theta_{\mathrm{Ed}, \mathrm{k}} \\
\Delta \varepsilon_{\mathrm{Ed}}
\end{array}\right\}
\end{gathered}
$$

and moreover: $\Delta M_{\mathrm{Ed}, \mathrm{i},} \Delta M_{\mathrm{Ed}, \mathrm{k}}$ - the incremental nodal moments, respectively, at ends "i" and " $\mathrm{k}$ ", $\Delta N_{\mathrm{Ed}}$ - the incremental axial force, $(E I)_{\mathrm{Tf}}=E_{\mathrm{Tf}} I-$ the nominal value of the frame element tangent stiffness in relation to the effect of the axial force on the flexural stiffness (different for tensile and compressive forces), $(E A)_{\mathrm{Tf}}=E_{\mathrm{Tf}} A$ - the nominal value of the frame element tangent stiffness in relation to the effect of the axial force on the axial stiffness (different for tensile and compressive forces), $I, A$ - the nominal values of the frame element section moment of inertia and gross area, $E_{\mathrm{Tf}}=\eta_{\mathrm{Nf}} E-$ the tangent modulus of elasticity (for compression according to the Shanley inelastic buckling theory accounting for the effects of geometric imperfections on the stiffness of slender compression members), $\eta_{\mathrm{Nf}}-$ the frame element stiffness 
degradation function, $E$ - modulus of elasticity, $L$ - element "i-k" system length, $\left[k_{\mathrm{T} \theta}\right]$ - the flexural tangent stiffness submatrix, $\Delta \theta_{\mathrm{Ed}, \mathrm{i}}, \Delta \theta_{\mathrm{Ed}, \mathrm{k}}$ - the incremental nodal rotations, and $\Delta \varepsilon_{\mathrm{Ed}}-$ the incremental generalized strain (the shortening/elongation of an imperfect element divided by the element system length $L$ ).

The flexural tangent stiffness submatrix is of the following form:

$$
\left[k_{\mathrm{T} \theta}\right]=\left[\begin{array}{cc}
s_{\text {sup }, \mathrm{ii}} & s_{\text {sup }, \mathrm{k}} \\
s y m m . & s_{\text {sup }, \mathrm{kk}}
\end{array}\right]
$$

where:

$s_{\text {sup,ii, }} s_{\text {sup,kk }}$ - the inelastic direct stiffness coefficients of the super-element, $s_{\text {sup, }, \mathrm{k}}-$ the inelastic crossstiffness coefficient of the super-element:

$$
\begin{aligned}
& s_{\text {sup }, \mathrm{ii}}=\frac{1}{\varphi}\left[s_{\mathrm{el}-\mathrm{pl}, \mathrm{ii}}+\varphi_{\mathrm{k}}\left(s_{\mathrm{el}-\mathrm{pl}, \mathrm{ii}} s_{\mathrm{el}-\mathrm{pl} \mathrm{kk}}-s_{\text {el-pl,ik }}^{2}\right)\right] \\
& s_{\text {sup }, \mathrm{kk}}=\frac{1}{\varphi}\left[s_{\mathrm{el}-\mathrm{pl} \mathrm{kk}}+\varphi_{\mathrm{i}}\left(s_{\mathrm{el}-\mathrm{pl}, \mathrm{ii}} s_{\mathrm{el}-\mathrm{pl}, \mathrm{kk}}-s_{\mathrm{el}-\mathrm{pl}, \mathrm{ik}}^{2}\right)\right] \\
& S_{\text {sup,ik }}=\frac{s_{\text {el-pl,ik }}}{\varphi} \\
& \varphi_{\mathrm{i}}=\frac{E_{\mathrm{Tf}} I}{L S_{\mathrm{jT}, \mathrm{i}}}, \varphi_{\mathrm{k}}=\frac{E_{\mathrm{Tf}} I}{L S_{\mathrm{jT}, \mathrm{k}}} \\
& \varphi=\left(1+\varphi_{\mathrm{i}} s_{\mathrm{el}-\mathrm{pl}, \mathrm{ii}}\right)\left(1+\varphi_{\mathrm{k}} s_{\mathrm{el}-\mathrm{pl}, \mathrm{kk}}\right)-\varphi_{\mathrm{i}} \varphi_{\mathrm{k}} s_{\mathrm{el}-\mathrm{pl}, \mathrm{ik}}^{2}
\end{aligned}
$$

and:

$S_{\mathrm{j} T, \mathrm{i},}, S_{\mathrm{jT}, \mathrm{k}}-$ the values of joint tangent stiffness at ends " $\mathrm{i}$ " and "k", $S_{\mathrm{el}-\mathrm{pl}, \mathrm{ii}}, S_{\mathrm{el}-\mathrm{pl}, \mathrm{kk}}-$ the inelastic direct stiffness coefficients of the line element, $s_{\mathrm{el}-\mathrm{pl}, \mathrm{i}}-$ the inelastic cross-stiffness coefficient of the line element.

The inelastic stiffness coefficients of the line element are given by:

$$
\begin{aligned}
& s_{\mathrm{el}-\mathrm{pl}, \mathrm{ii}}=\left[s_{\mathrm{ii}}-\frac{s_{\mathrm{ik}}^{2}}{s_{\mathrm{kk}}}\left(1-\eta_{\mathrm{M}, \mathrm{k}}\right)\right] \eta_{\mathrm{M}, \mathrm{i}}, \\
& s_{\mathrm{el}-\mathrm{pl}, \mathrm{kk}}=\left[s_{\mathrm{kk}}-\frac{s_{\mathrm{ik}}^{2}}{s_{\mathrm{ii}}}\left(1-\eta_{\mathrm{M}, \mathrm{i}}\right)\right] \eta_{\mathrm{M}, \mathrm{k}}
\end{aligned}
$$




$$
s_{\mathrm{el}-\mathrm{pl}, \mathrm{ik}}=s_{\mathrm{ik}} \eta_{\mathrm{M}, \mathrm{i}} \eta_{\mathrm{M}, \mathrm{k}}
$$

where:

$s_{\mathrm{ii}}=s_{\mathrm{kk}}-$ the elastic direct second-order stiffness coefficients for the line element, $s_{\mathrm{ik}}-$ the elastic crosssecond-order-stiffness coefficient for the line element, $\eta_{\mathrm{M}, \mathrm{i}}, \eta_{\mathrm{M}, \mathrm{k}}-$ the flexural stiffness degradation functions at ends "i" and "k" of frame element i-k.

\subsection{MODELLING OF BRACING SUBSTRUCTURE TRUSS ELEMENT}

The incremental relationship for the truss brace consisting of a line element with nominally hinged end joints, transferring predominantly the axial force and not interacting with the moment-resisting substructure in the moment distribution and redistribution processes under applied loads, is given by:

$$
\Delta N_{\mathrm{Ed}}=k_{\mathrm{Tt}} \Delta \varepsilon_{\mathrm{Ed}}
$$

where:

$k_{\mathrm{Tt}}-$ the truss element tangent stiffness in LCS as the single term, $k_{\mathrm{Tt}}=(E A)_{\mathrm{Tt}}=E_{\mathrm{Tt}} A-$ the nominal value of the truss element tangent stiffness, $E_{\mathrm{Tt}}=\eta_{N t} E$ - the tangent modulus of elasticity obtained for an imperfect truss element treated as a perfect equivalent with a hypothetical stress-strain relationship reproducing in compression the buckling behaviour in terms of member behaviour pre-limit and post-limit ranges, $\eta_{N t}-$ the truss element axial stiffness degradation function, $A$ - the truss element gross cross-section area.

\subsection{EQUILIBRIUM IN GLOBAL COORDINATES AND SOLVING PROCEDURE}

Transforming the local matrices to the stationary GCS (Global Coordinate System), the assembled set of braced frame equilibrium equations takes the following format for proportional loads [8]:

$$
\left[K_{T}\right]\{\Delta r\}=\{\Delta R\}
$$

where:

$\left[K_{\mathrm{T}}\right]$ - the global tangent stiffness matrix of the assembled frame and truss matrices in GCS, $\{\Delta r\}-$ the incremental generalized nodal displacement vector in GCS, $\{\Delta R\}$ - the unbalanced generalized nodal load vector 


$$
\{\Delta R\}=\alpha_{\mathrm{Ed}}\{R\}-\{F\}
$$

where:

$\{R\}$ - the reference structure nodal load vector at the design level, $\alpha_{E d}\{R\}$ - the load vector for each incremental step characterized by the load multiplier $\alpha_{E d}$ which describes the load level at the current load increment with reference to the design load level, $\{F\}$ - the element forces vector in global coordinates assembled from the local vectors $\{Q\}$ evaluated for the current load increment.

Analysis has to be generally performed in an incremental-iterative way. At each incremental step, the iterations are to be carried out in order to impose the zero value of unbalanced forces. Advanced analysis is carried out until the design load level is reached, i.e. when $\alpha_{E d}=1$, or up to the limit point attainment on the equilibrium path, i.e. when $\left|\left[K_{T}\right]\right| \leq 0$, for which the load multiplier is $\alpha_{\mathrm{Ed}}=\alpha_{\mathrm{ult}}$.

For non-proportional load combinations, the application of several load sets is suggested in a sequential way, one by one, within their prescribed design values. In inelastic design, the choice of the load sequence may affect the ultimate load so that a critical load sequence path has to govern. For two load sets, the unbalanced generalized nodal load vector is calculated independently for two sequential stages. For the $1^{\text {st }}$ stage, Eq. (2.1) holds the variables which are given the subscript 1 . It is valid until the load factor $\alpha_{E d, 1}$ reaches its maximum prescribed value $\alpha_{E d, 1, \text { max }}$ provided that $\llbracket\left[K_{T}\right] \geq 0$. In the $2^{\text {nd }}$ stage, Eq. (2.1) becomes as follows:

$$
\left\{\Delta R_{2}\right\}=\alpha_{\mathrm{Ed}, 1, \max }\left\{R_{1}\right\}+\left(\alpha_{\mathrm{Ed}, 2}\left\{R_{2}\right\}-\left\{F_{2}\right\}\right)
$$

where:

$\left\{R_{2}\right\},\left\{F_{2}\right\}, \alpha_{E d, 2}-$ variables referring to the $2^{\text {nd }}$ stage of analysis with the same meaning as those with a subscript of 1 referring to the $1^{\text {st }}$ stage of analysis.

Analysis is carried out until the design load level of the second load combination is reached, i.e. when $\alpha_{\mathrm{Ed}, 2}=1$, or up to the limit point attainment on the equilibrium path, i.e. when $\mid\left[K_{T}\right] \leq 0$, for which the load multiplier is $\alpha_{\mathrm{Ed}, 2}=\alpha_{\mathrm{ult}}$.

In the CSD advanced analysis presented hereafter, a maximum of two-stage sequential load application history is assumed and combined with a simple incremental solving procedure. In this 
procedure, it is reasonable to assume that at each incremental step the equilibrium position is closely approximated, i.e. that $\{F\} \approx\{0\}$, provided that the incremental values of the load multiplier are kept small enough for no iterations to be performed. In order to fulfil this assumption, the sensitivity of the equilibrium path evaluation in relation to the size of the load increment is tested and recommendations in this regard are presented for engineering practices.

\section{MODELLING OF STIFFNESS DEGRADATION FUNCTIONS AND THEIR IMPLEMENTATION}

\subsection{FRAME SUBSTRUCTURE ELEMENT STIFFNESS DEGRADATION FUNCTIONS}

The starting point for the development of the stiffness degradation function $\eta_{\mathrm{Nf}}$ was to adopt the unified formulation of a hypothetical stress-strain relationship of the perfect member which reproduces the behaviour of its imperfect counterpart. This yields:

$$
\sigma=\left\{\begin{array}{cl}
{\left[\left(\frac{\varepsilon}{\varepsilon_{\mathrm{y}}}\right)^{-n}+\left(1+\frac{E_{\mathrm{H}}}{E} \frac{\varepsilon}{\varepsilon_{\mathrm{y}}}\right)^{-n}\right]^{-1 / n}} & \text { for } \quad \varepsilon \geq 0 \\
-\left[\left(\frac{E_{0}}{E} \frac{|\varepsilon|}{\varepsilon_{\mathrm{y}}}\right)^{-n}+\left(1+\frac{E_{\mathrm{H}}}{E} \frac{|\mathcal{\varepsilon}|}{\varepsilon_{\mathrm{y}}}\right)^{-n}\right]^{-1 / n} & \text { for } \quad \varepsilon<0
\end{array}\right.
$$

where:

$\sigma, \varepsilon$ - the generalized stress equal to $N_{\mathrm{Ed}} / f_{\mathrm{y}} A$ and the generalized strain $\left(u_{\mathrm{k}}-u_{\mathrm{i}}\right) / L$ of the perfect element substituting its imperfect counterpart, $u_{\mathrm{i}}, u_{\mathrm{k}}$ - displacements in LCC along the $\mathrm{x}$ axis for ends "i" and " $\mathrm{k}$ ", $f_{\mathrm{y}}-$ the steel yield strength, $E_{0}$ - the slenderness ratio dependent equivalent modulus of elasticity of imperfect compression members, ranging from the asymptotic value of $E / \gamma$ to its initial value of $E, \varepsilon_{y}=f_{y} / E$ - the yield strain, $E_{H}-$ the modulus of isotropic hardening, and $n-$ an imperfection factor.

Ratio $E_{0} / E$ approaches its asymptotic value $1 / \gamma$ for very slender compression members, thereby accounting for the effects of their geometric imperfections: 


$$
\frac{E_{0}}{E}=\left\{\begin{array}{ccc}
1 & \text { for } & \bar{\lambda} \leq 0,2 \\
\frac{1+(\bar{\lambda}-0,2)^{2}}{1+\lambda(\bar{\lambda}-0,2)^{2}} & \text { for } & \bar{\lambda}>0,2
\end{array}\right.
$$

where:

$\bar{\lambda}$ - the relative slenderness ratio according to [20].

For tension members, the above-mentioned ratio is as it would be for compression members with a relative slenderness ratio of less than 0,2 . Since buckling multiple curves are recommended by Eurocode 3 [20], there is no one single stiffness degradation function but a set of multiple degradation functions dependent upon different sections, proportions of their dimensions, and directions of in-plane bending and buckling. The derivation of these functions in compression conforms with Shanley's bifurcation theory of inelastic buckling and it has been presented in [21] (denoted there by B). Model parameters $n$ and $\gamma, E_{\mathrm{H}} / E$ were calibrated in [21] in order to reproduce Eurocode's buckling curves from the uppermost $\mathrm{a}_{0}$ to the lowest one $\mathrm{d}$.

The stiffness degradation function $\eta_{\mathrm{Nf}}$ for the frame substructure beam-column element is of the same format for calculating both tension and compression, provided that for tension it pertains to the compression of the stocky member, i.e. a relative slenderness ratio which is equal or less than 0,2 . The stiffness degradation function takes the following form:

$$
\eta_{N f}=\left[\left(\frac{E_{0}}{E} \frac{|\mathcal{\varepsilon}|}{\varepsilon_{y}}\right)^{-n}+\left(1+\frac{E_{H}}{E} \frac{|\varepsilon|}{\varepsilon_{y}}\right)^{-n}\right]^{-(1+1 / n)}\left[\frac{E_{0}}{E}\left(\frac{E_{0}}{E} \frac{|\varepsilon|}{\varepsilon_{y}}\right)^{-(1+n)}+\frac{E_{H}}{E}\left(1+\frac{E_{H}}{E} \frac{|\varepsilon|}{\varepsilon_{y}}\right)^{-(1+n)}\right]
$$

As a result, for a certain section and direction of buckling, the hypothetical stress-strain relationships and stiffness degradation functions are obtained and illustrated in Fig. 1. The stiffness degradation curves presented in Fig. $1 \mathrm{~b}$ are dependent upon the generalized strain. From the computational point of view, it is more convenient to present these curves in coordinates $\eta_{\mathrm{Nf}}$ and $\alpha_{\mathrm{N}}=\sigma / f_{y}$ since $N_{\mathrm{Ed}}=\sigma_{\mathrm{Ed}} A$ may be calculated directly at every stage of incremental analysis for frame elements. Knowing $N_{\mathrm{Ed}}$, and therefore also the stress $\sigma_{\mathrm{Ed}}$ and the stress state parameter $\alpha_{\mathrm{N}}$, the relative generalized strain $\varepsilon / \varepsilon_{y}$ may be calculated from Eq. (3.1) and then substituted into Eq. (3.2) for the stiffness degradation function $\eta_{\mathrm{Nf}}$ representing the effect of axial force on the flexural stiffness degradation. The degradation curves obtained this way are presented in Fig. 1c. The areas 
shaded in Fig. 1 are bounded by lines corresponding to buckling curves $\mathrm{a}_{0}$ and d. One can notice that, in tension, the stress-strain and stiffness degradation curves are identical to those in compression for elements whose slenderness ratio is equal to or less than 0,2 .

a)

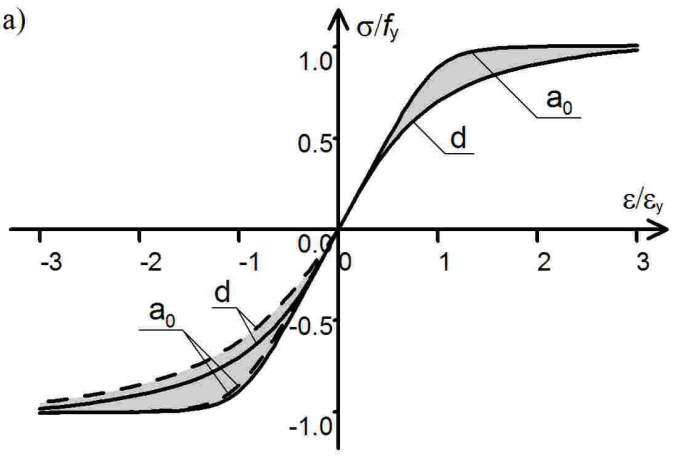

c)

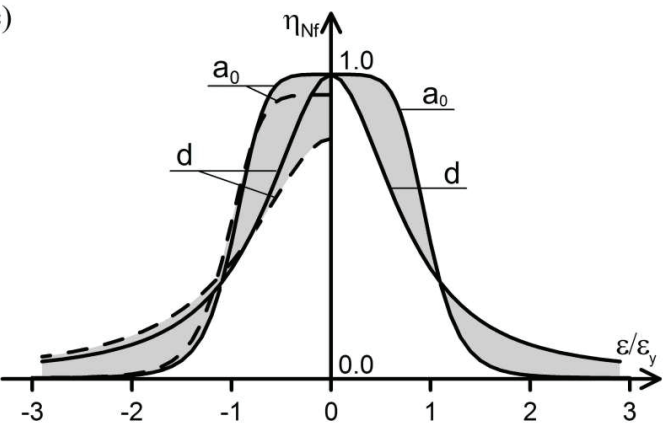

b)

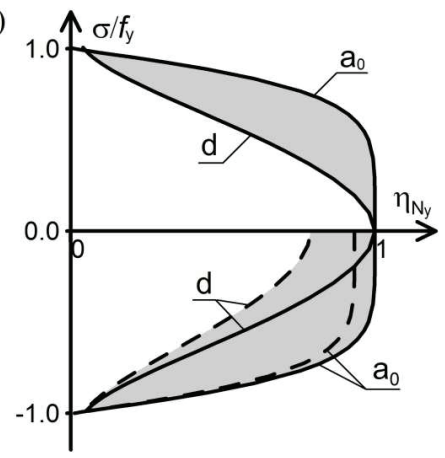

- Compresion for $\bar{\lambda} \leq 0,2$ and tension

- - Compresion for $\bar{\lambda}=3$

Fig. 1. Illustration of the effect of axial force on frame element stiffness: a) Hypothetical stress-strain relationship, b) Degradation function $\eta_{\mathrm{Nf}}$ referring to the relative axial force, c) Degradation function $\eta_{\mathrm{Nf}}$ referring to the relative axial strain

For beam-column and beam-tie elements, flexural degradation functions $\eta_{\mathrm{Mi}}$ and $\eta_{\mathrm{Mk}}$ for ends "i" and " $\mathrm{k}$ " are assumed to be of the same format as $\eta_{\mathrm{Nf}}$ in tension, i.e. adopting $E_{0} / E=1$ in Eq. (3.2). For bending about any principal axis, they are calculated with regard to force state parameters $\alpha_{\mathrm{M}, \mathrm{i}}=$ $M_{\mathrm{Ed}, \mathrm{i}} / M_{\mathrm{N}, \mathrm{Rk}}$ and $\alpha_{\mathrm{M}, \mathrm{k}}=M_{\mathrm{Ed}, \mathrm{k}} / M_{\mathrm{N}, \mathrm{Rk}}$, respectively, where $M_{\mathrm{N}, \mathrm{Rk}}$ is the section resistance in bending about the considered principal axis reduced with regard to axial force $\mathrm{N}_{\mathrm{Ed}}$, and $M_{\mathrm{Ed}, \mathrm{i}}, M_{\mathrm{Ed}, \mathrm{k}}$ are the bending moments at the beginning and end of the frame element. Stress resultant state parameters $\alpha_{\mathrm{M}, \mathrm{i}}$ and $\alpha_{\mathrm{M}, \mathrm{k}}$ are generally different at both ends, therefore degradation functions $\eta_{\mathrm{Mi}}$ and $\eta_{\mathrm{Mk}}$ are also of different values for both ends. 
It must be stressed that derived stiffness degradation function $\eta_{\mathrm{Nf}}$ is used to describe tangent flexural stiffness $(E I)_{\mathrm{Tf}}$ and tangent axial stiffness $(E A)_{\mathrm{Tf}}$ of frame subsystem elements, and it is different from that derived for bracing subsystem elements (see the following section).

Fig. 2 shows the concept of stiffness degradation functions $\eta_{\mathrm{Nf}}$ and $\eta_{\mathrm{M}}$ for ends "i" and "k" of the frame element, i.e. respectively $\eta_{\mathrm{Mi}}$ and $\eta_{\mathrm{Mk}}$. The adopted interaction curve of section resistance under bending about the $y-y$ axis and the axial force is set according to the recommendations of

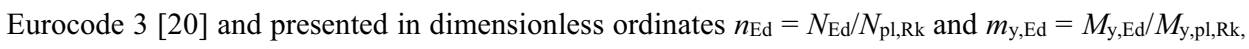
where $N_{\mathrm{pl}, \mathrm{Rk}}$ and $M_{\mathrm{y}, \mathrm{pl}, \mathrm{Rk}}$ are the section resistances according to [20]. Let's consider a situation where points $\mathrm{A}_{\mathrm{Ed}, \mathrm{i}}$ and $\mathrm{A}_{\mathrm{Ed}, \mathrm{k}}$ represent actual stress resultant state at ends "i" and " $\mathrm{k}$ " for a given value of $n_{\mathrm{Ed}}$. 


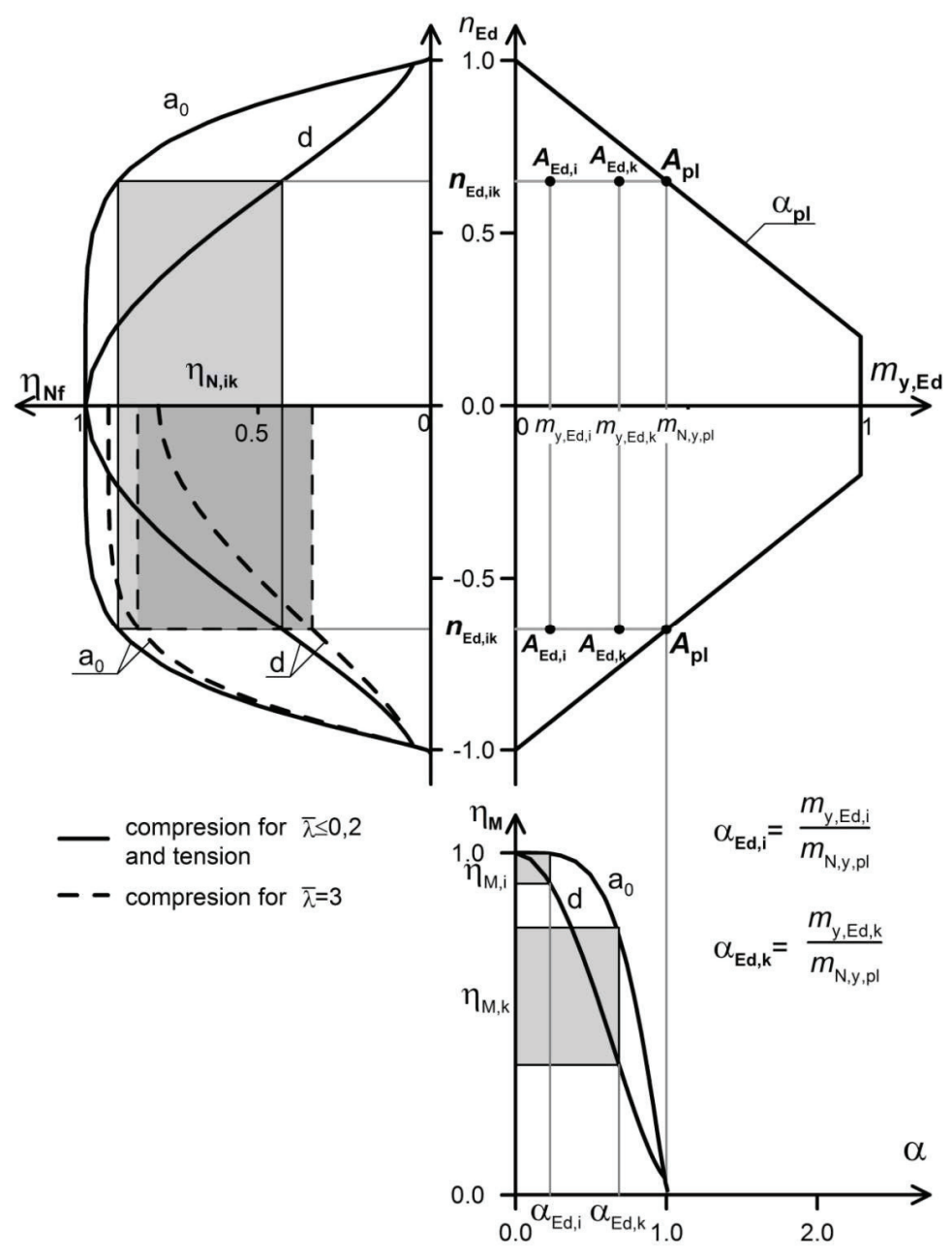

Fig. 2. Illustration of the stiffness degradation modelling technique in CSD advanced analysis Since the axial force is constant along element length, points $A_{E d, i}$ and $A_{E d, k}$ have the same force state parameter $\alpha_{\mathrm{N}}=n_{\mathrm{Ed}, \mathrm{ik}}$ for the evaluation of tangent modulus of elasticity $E_{\mathrm{Tf}}$ for the element. The area enclosed in compression and tension by the solid lines within the rectangle and marked by the lighter grey colour represents the variability region of stiffness degradation faction $\eta_{\mathrm{Nf}}$ for stocky beam-column (with a slenderness ratio of $\bar{\lambda} \leq 0,2$ ) and for beam-tie elements. The darker grey colour represents the variability region of stiffness degradation faction $\eta_{\mathrm{Nf}}$ for slender beamcolumn elements (the curve is constructed for a chosen slenderness of $\bar{\lambda}=3$ ). The areas enclosed 
by solid lines within a stiffness degradation function of $\eta_{\mathrm{M}}$ (in reference to $\eta_{\mathrm{Mi}}$ and $\eta_{\mathrm{Mk}}$ at member ends "i" and "k") and marked by the lighter grey colour represent the variability region of stiffness degradation faction $\eta_{\mathrm{M}}$ for beam-ties and beam-columns, regardless of the slenderness ratio of the latter.

One can conclude that for larger axial forces there is a greater contribution of the axial force than the bending moment to the stiffness degradation ( $\eta_{\mathrm{Nf}}$ is smaller than $\eta_{\mathrm{M}, \mathrm{i}}$ or $\eta_{\mathrm{M}, \mathrm{k}}$ ). This case is representative of the behaviour of frame verticals (struts). For smaller axial forces, $\eta_{\mathrm{Nf}}$ is closer to unity and the contribution of larger bending moments is more pronounced than the axial force. This case is representative of the behaviour of frame horizontals (rafters). It has to be noted that in cases of zero bending moments and nonzero axial forces in frame members, stiffness degradation functions $\eta_{\mathrm{M}, \mathrm{i}}=\eta_{\mathrm{M}, \mathrm{k}}=1$ and stiffness degradation is associated only with the effect of axial forces through function $\eta_{\mathrm{Nf}}$.

Recently, European stiffness degradation functions have also been derived in [22] but in a different way, namely directly from Eurocode's buckling curve formulation, and were next used for the purpose of in-plane steel frame design using advanced analysis [23].

\subsection{TRUSS ELEMENT STIFFNESS DEGRADATION FUNCTIONS}

The stiffness degradation model adopted for truss members in the RPH advanced analysis in [8] assumes that stiffness degradation function $\eta_{\mathrm{Nt}}$ of a compressed brace is of the same form as $\eta_{\mathrm{Nf}}$ for the frame member, i.e. following Shanley's tangent modulus theory. Furthermore, the axial force for the compressed brace is limited to the value of $N_{\mathrm{b}, \mathrm{Rk}}=\sigma_{\mathrm{b}, \mathrm{Rk}} A$ above which the brace cannot take up an increased load, i.e. its tangent stiffness remains equal to zero as at the limit point of the brace equilibrium path and the forces opposite and equal to the brace buckling resistance are included in the structure force vector with their constant values for the further stages of incremental analysis. This assumption overestimates the structure's resistance since brace response after reaching buckling resistance is of a softening nature.

The model adopted herein is based on one developed in [21] and is referred to as the divergencebased stiffness degradation model (denoted as model D). It allows for a more accurate evaluation of the response of axially-loaded members across a more full range of deformations than those from other studies since it includes (more precisely) the force-softening effect after buckling resistance is reached. The curve of this model in compression is shown in Fig. 3 and combined with a tension curve same as in function $\eta_{\mathrm{Nf}}$. The dimensionless force-deformation relationship in compression is 
represented by the curve exhibiting the pre-limit range for $|\varepsilon| / \varepsilon_{\mathrm{y}}<\left|\varepsilon_{\mathrm{b}, \mathrm{Rk}}\right| / \varepsilon_{\mathrm{y}}$ (i.e. also $\left|\sigma_{\mathrm{Ed}}\right| / f_{\mathrm{y}}<$ $\left.\left|\sigma_{\mathrm{b}, \mathrm{Rk}}\right| / f_{\mathrm{y}}\right)$, the limit point at the buckling level identified by ordinates $\sigma_{\mathrm{b}, \mathrm{Rk}} / f_{\mathrm{y}}$ and $\varepsilon_{\mathrm{b}, \mathrm{Rk}} / \varepsilon_{\mathrm{y}}$, and, finally, the post-limit range for $|\varepsilon| / \varepsilon_{\mathrm{y}}>\left|\varepsilon_{\mathrm{b}, \mathrm{Rk}}\right| / \varepsilon_{\mathrm{y}}$ (where $\left|\sigma_{\mathrm{Ed}}\right| f_{\mathrm{y}}<\left|\sigma_{\mathrm{b}, \mathrm{Rk}}\right| f_{\mathrm{y}}$ same as for the pre-limit range, but for the deformation of increased values $\left.|\varepsilon| / \varepsilon_{\mathrm{y}}>\left|\varepsilon_{\mathrm{b}, \mathrm{Rk}}\right| / \varepsilon_{\mathrm{y}}\right)$.
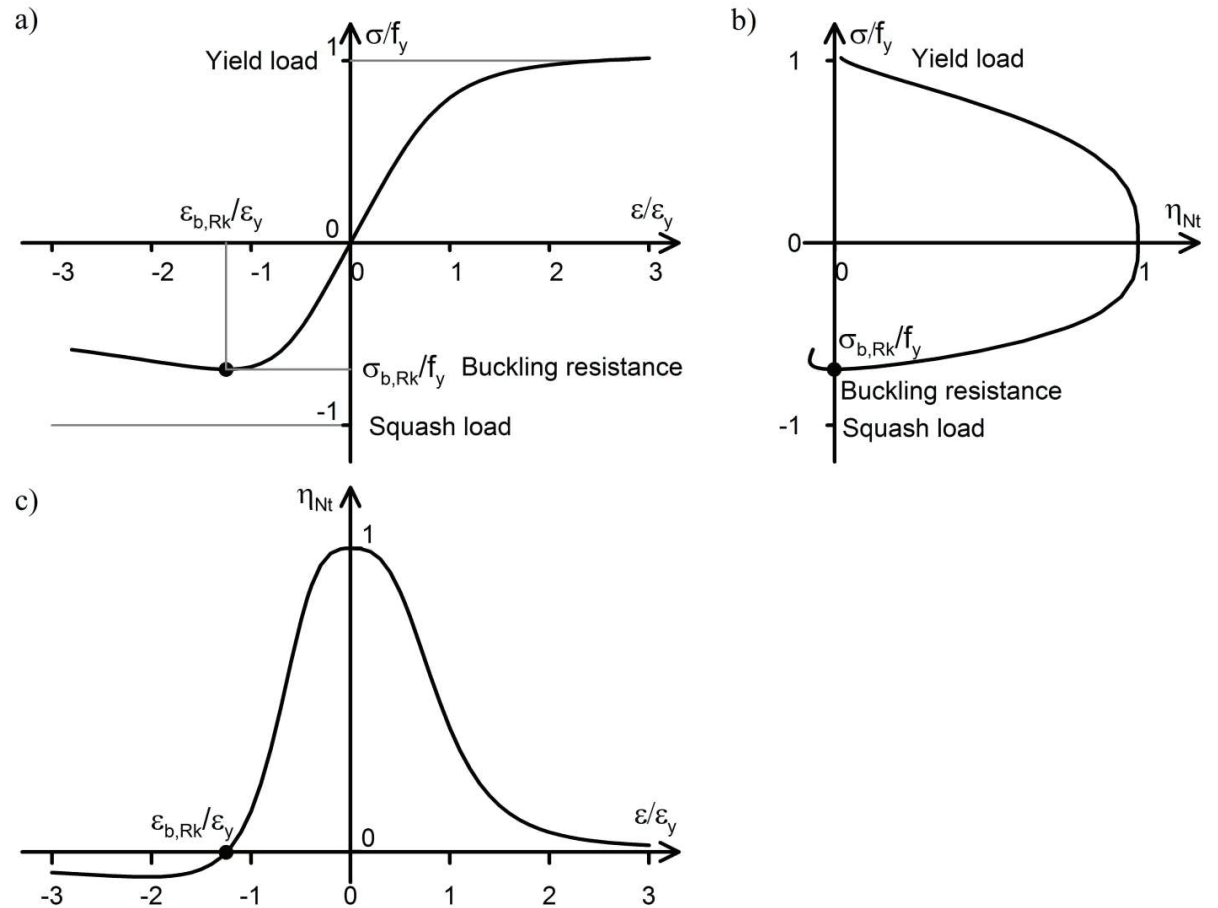

Fig. 3. Conceptual sketch of stiffness degradation function $\eta_{\mathrm{Nt}}$ for truss bracing; a) Hypothetical stress-strain relationship; b) Degradation function of the axial stiffness expressed with regard to the axial force,

c) Degradation function of the axial stiffness expressed with regard to the axial deformation

Recently, the model conceptually presented in [21] was further developed and validated for angle section braces in [18]. Two brace-end conditions were considered for which the following basic relationship holds true: 


$$
\sigma=f_{\mathrm{y}}\left\{\begin{array}{cc}
{\left[\left(\frac{\varepsilon}{\varepsilon_{\mathrm{y}}}\right)^{-n}+\left(1+\frac{E_{\mathrm{H}}}{E} \frac{\varepsilon}{\varepsilon_{\mathrm{y}}}\right)^{-n}\right]^{-1 / n}} & \text { for } \varepsilon \geq 0 \\
-\left[\left(\frac{\left|\sigma_{\mathrm{E}}\right|}{f_{\mathrm{y}}}\right)^{-n}+\sum_{\mathrm{j} \leq 2}\left(\frac{\sigma_{\mathrm{bif}, \mathrm{j}}}{f_{\mathrm{y}}}\right)^{-n}+\left(1+\frac{E_{\mathrm{H}}}{E} \frac{|\varepsilon|}{\varepsilon_{\mathrm{y}}}\right)^{-n}+\alpha_{\mathrm{u}}^{n}\left(\frac{\sigma_{\mathrm{F}} / f_{\mathrm{y}}}{|\varepsilon| / \varepsilon_{\mathrm{y}}}\right)^{-m n}\right]^{-1 / n} & \text { for } \varepsilon<0
\end{array}\right.
$$

where:

$n$ - the imperfection factor, $\sigma_{\mathrm{E}} / f_{\mathrm{y}}=\varepsilon / \mathcal{E}_{\mathrm{y}}$ for centric compression and for eccentric compression $\sigma_{\mathrm{E}} / f_{\mathrm{y}}$ is the argument of a nonlinear inverse function $\varepsilon / \varepsilon_{\mathrm{y}}=f\left(\sigma_{\mathrm{E}} / f_{\mathrm{y}}\right)$, which is the sum of the axial shortening of the axially compressed member and the shortening resulting from the bowing effect due to bending imposed on the member by axial forces applied through eccentric end connections, $\sigma_{\mathrm{bif}, j}-$ the bifurcation stress according to the linear elastic stability theory, $j$ - number of uncorrelated instability modes (governing flexural and torsional for bisymmetric section members), $a_{\mathrm{u}}$ - the section shape factor, the value of which is a constant dependent on the section type and type of pre-buckling deformations, $\sigma_{\mathrm{F}}-$ minimum of flexural bifurcation stress about section principal axes, $m$ - the parameter for compressed braces equal to 0,5 for axially compressed members and for angles with the eccentric compression in the plane of section symmetry, otherwise equalling 1,0 .

The axial stiffness reduction function of a truss element is then calculated as follows:

$$
\begin{aligned}
& \text { tension } \\
& ]^{-1-\frac{1}{n}}\left[\left(\frac{\varepsilon}{\varepsilon_{\mathrm{y}}}\right)^{-n}\right. \\
& \text { compression }
\end{aligned}
$$

$$
\eta_{\mathrm{Nt}}=\left[\left(\frac{\left|\sigma_{\mathrm{E}}\right|}{f_{\mathrm{y}}}\right)^{-n}+\sum_{\mathrm{j} \leq 2}\left(\frac{\sigma_{\mathrm{bif}, \mathrm{j}}}{f_{\mathrm{y}}}\right)^{-n}+\left(1+\frac{E_{\mathrm{H}}}{E} \frac{|\varepsilon|}{\varepsilon_{\mathrm{y}}}\right)^{-n}+a_{\mathrm{u}}^{n}\left(\frac{\sigma_{\mathrm{F}} / f_{\mathrm{y}}}{|\varepsilon| / \varepsilon_{\mathrm{y}}}\right)^{-m n}\right]^{-1-\frac{1}{n}} .
$$

$$
\cdot\left[\varepsilon_{\mathrm{y}}\left(\frac{\left|\sigma_{\mathrm{E}}\right|}{f_{\mathrm{y}}}\right)^{-n-1} \cdot \frac{d}{d|\varepsilon|}\left(\frac{\left|\sigma_{\mathrm{E}}\right|}{f_{\mathrm{y}}}\right)+\frac{E_{\mathrm{H}}}{E}\left(1+\frac{E_{\mathrm{H}}}{E} \frac{|\varepsilon|}{\varepsilon_{\mathrm{y}}}\right)^{-n-1}-m a_{\mathrm{u}}^{n}\left(\frac{\sigma_{\mathrm{F}} / f_{\mathrm{y}}}{|\varepsilon| / \varepsilon_{\mathrm{y}}}\right)^{-m n}\left(\frac{\varepsilon_{\mathrm{y}}}{|\varepsilon|}\right)^{1-m n}\right]
$$

This validated model illustrated in Fig. 4 is for an angle-rolled section connected through one leg with the use of bolts (marked as B) and fork-connected with the use of welds (marked as W). It is utilized hereafter in validating the developed CSD advanced analysis and further recommended for 
implementation in practical design as well as in the assessment of resistance and serviceability of existing structures.
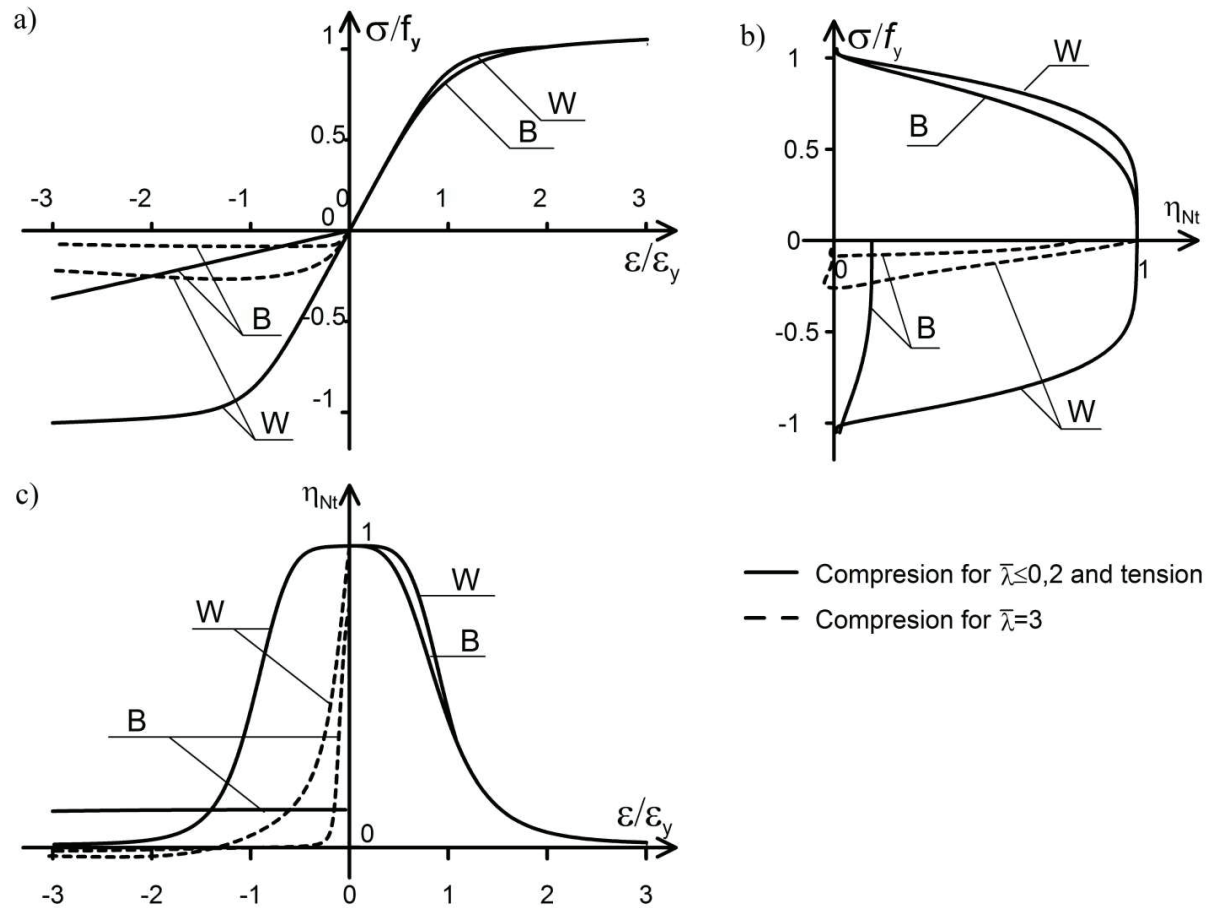

Fig. 4. Illustration of stiffness degradation function $\eta_{\mathrm{Nt}}$; a) Hypothetical stress-strain relationship; b) Stiffness degradation function in terms of axial deformation, c) Stiffness degradation function in terms of axial force

All curves presented in Fig. 4 are drawn for equal leg angle braces whose slenderness ratio $\left(\lambda_{\mathrm{v}}=\right.$ $L / i_{\mathrm{v}}$ where $i_{v}$ is the minimum section radius of gyration) is calculated for the same lengths of bolted and welded braces,. For comparison purposes, the effect of different buckling length factors for bolted and welded braces is disregarded. Two design situations are considered, namely a case of a stocky compression element (relevant also for tension) and a case of a slender compression element (with the chosen value of the relative slenderness ratio equal to 3 ). The curve related to the former situation is marked by the solid line, while the curve related to the latter by the broken line.

The following conclusions can be drawn:

1. Brace element degradation curves in tension and compression start from the same level of $\eta_{\mathrm{Nt}}=1$ for the $\mathrm{W}$ braces in contrast to the frame element degradation curves presented in Fig. 1. 
2. For tension, curves $\sigma / f_{\mathrm{y}}-\varepsilon / \varepsilon_{\mathrm{y}}$ and $\eta_{\mathrm{Nt}}-\varepsilon / \varepsilon_{\mathrm{y}}\left(\right.$ or $\eta_{\mathrm{Nt}}-\sigma / f_{\mathrm{y}}$ ) are similar for both types of brace-end connections. This results from the fact that in Eqns. (3.3) and (3.4) different values of $n$ represent the effect of imperfections on the equilibrium path.

3. Important differences between degradation functions are visible only for compression. The initial stiffness reduction needs to be considered only for the B braces, bolted through one leg to the gusset plate, and is more pronounced for shorter braces than for longer ones.

4. A sharper axial force drop in the post-limit range is observed for braces with medium slenderness ratio than for those of stocky and slender braces.

5. As a result of the $\sigma / f_{\mathrm{y}}$ drop after attainment of the limit point on the brace equilibrium path, there is a change of sign of the $\eta_{\mathrm{Nt}}$ function after which the stiffness approaches asymptotically the zero value (Figs. $4 \mathrm{~b}$ and $4 \mathrm{c}$ ).

\subsection{NUMERICAL IMPLEMENTATION}

The advanced CSD analysis has been initially implemented into the pilot computer program ECIDA [10] and the results obtained using the program were verified using the results obtained from the analytical formulae of Eurocode 3 [20] related to the column buckling resistance curves and to the beam-column interaction curves under strong axis bending and compression. The developed computer program has the following attributes:

1. Utilizes the structure of source code PHINGE programmed by J.Y. Richard Liew [24].

2. Uses an automatic load adjustment technique to trace the second order inelastic load-deflection response of planar frames from the initiation of loading history up to the maximum load applied on the frame.

3. Includes a library of different joint nonlinear moment-rotation characteristics according to the classification made available in [25], piece-linear or curvilinear with resistance attained asymptotically at the limit point or at a notional value in cases of the post-limit stiffness hardening.

4. Introduces new element stiffness degradation functions.

As it has been stated earlier (see subsection 2.3), the simple incremental method of solving the frame nonlinear equilibrium equations is used, with no iterations for the elimination of unbalanced nodal forces error. This straightforward solution technique is computationally effective but care has to be taken for the size of applied load steps. An improved accuracy is obtained by using the automatic reduction of load increments in order to keep the change in the stiffness degradation functions in two successive load steps within a predefined limit [8]. A load increment which is too 
large may also result in over passing the limit point, therefore the automatic reduction in load incrementation helps to closely estimate the limit point on the equilibrium path as well as the nodal displacements and the member second-order stress resultants. The load increment reduction is especially applied when the following situations occur:

a. There is a change in the element stiffness parameter exceeding a predefined tolerance.

b. There is a violation of the cross-sectional resistance when the axial force is larger than the yield load or the moment is larger than the reduced plastic moment.

c. The determinant of the structure tangent stiffness matrix is singular.

A simplified flow chart of the execution of the ECIDA program is shown in Fig. 5. The main subroutines of ECIDA associated with the proposed CSD advanced analysis concept are as follows:

Subroutine FETSTIF: Calculates the values of frame member stiffness degradation functions. The input parameter is axial force $N_{\mathrm{Ed}}$ converted into its dimensionless counterpart $n_{\mathrm{Ed} \text {,ik }}$ as well as force state parameters $\alpha_{\mathrm{Ed}, \mathrm{i}}$ and $\alpha_{\mathrm{Ed}, \mathrm{k}}$. First, the generalized strain is calculated from Eq. (3.1) using an iterative method and prescribed a tolerance limit, then the predicted value is used for the calculation of $\eta_{\mathrm{Nf}}$ according to Eq. (3.2). Second, the notional force state deformation predictors are calculated from Eq. (3.1) using $\alpha_{\mathrm{Ed}, \mathrm{i}}$ and $\alpha_{\mathrm{Ed}, \mathrm{k}}$ instead of $n_{\mathrm{Ed}, \mathrm{k}}$, then the predicted values are used for the calculation of $\eta_{\mathrm{M}, \mathrm{i}}$ and $\eta_{\mathrm{M}, \mathrm{k}}$ according to Eq. (3.2).

Subroutine ESTIFF: Calculates force state parameters $\alpha_{\mathrm{Ed}, \mathrm{i}}$ and $\alpha_{\mathrm{Ed}, \mathrm{k}}$ for the end sections of the frame element. The input parameters are axial force $N_{\mathrm{Ed}}$ as well as bending moments $M_{\mathrm{Ed,i}}$ and $M_{\mathrm{Ed}, \mathrm{k}}$ converted to their dimensionless values. Using the these values, predictors $\alpha_{\mathrm{Ed}, \mathrm{i}}$ and $\alpha_{\mathrm{Ed}, \mathrm{k}}$ are calculated to be the input parameters for the subroutine FETSTIF.

Subroutine TETSTIF: Calculates the value of the truss member stiffness degradation function. The input parameter is the axial deformation $\left(u_{\mathrm{k}}-u_{\mathrm{i}}\right)$ converted into its dimensionless counterpart $\varepsilon=\left(u_{\mathrm{k}}-u_{\mathrm{i}}\right) / \mathrm{L}$. For its positive value (tension), stiffness degradation function $\eta_{\mathrm{Nt}}$ is calculated according to Eq. (3.4a) same as for the frame member, but with an assumption of $E_{0}=E$. For its negative value (compression), stiffness degradation function $\eta_{\mathrm{Nt}}$ is calculated according to Eq. (3.4b). 


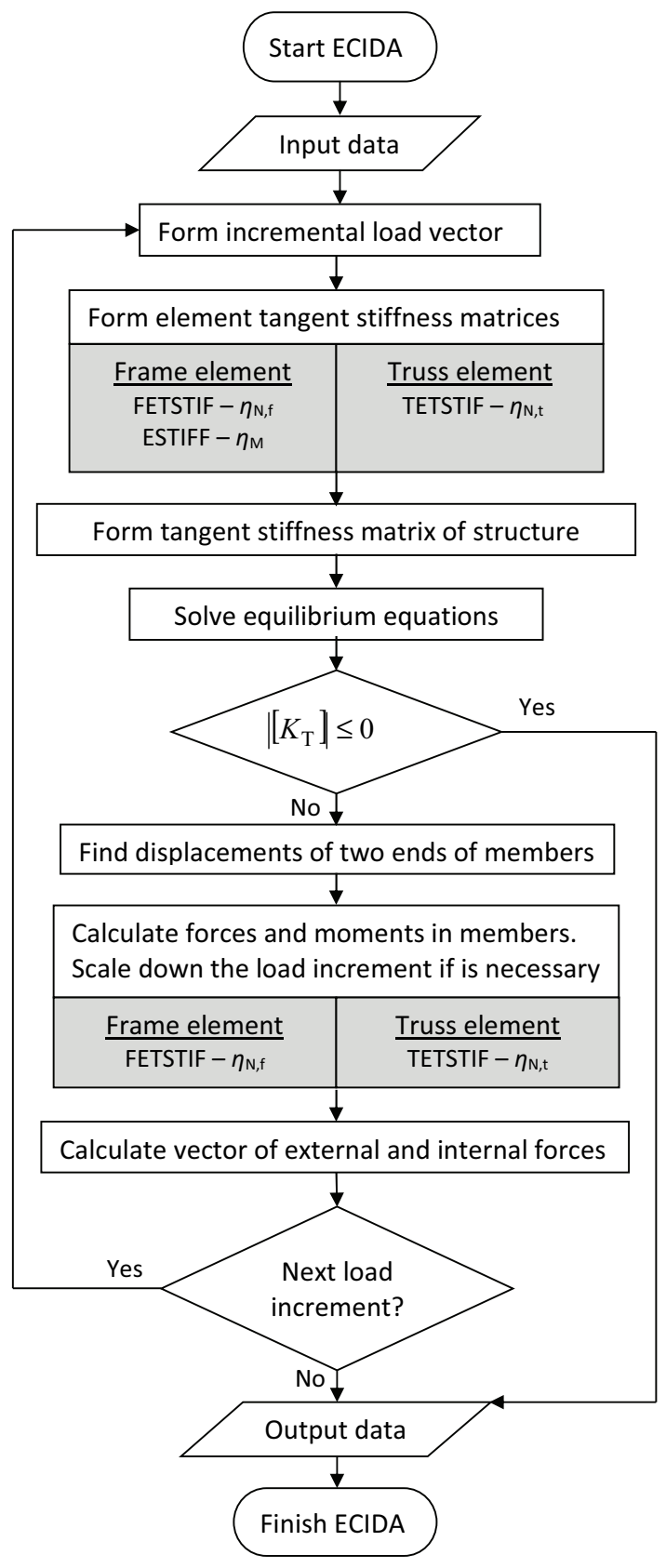

Fig. 5 Flow chart of ECIDA program execution 


\section{EXPERIMENTAL INVESTIGATIONS}

Experimental investigations have been recently conducted by the author in the Laboratory of the Metal Structures Department of the Warsaw University of Technology and presented in [19]. These investigations were used in [18] with regard to the validation of the theoretical brace model of an equivalent truss member. The description of the specimens used, testing stand, and testing procedure have been presented in [18] in detail, mostly in reference to the validation of the brace model of the tested frames. A brief summary presented hereafter is therefore related only to the global response of frame specimens to be used for the validation of CSD advanced analysis summarized earlier in section 3 .

\subsection{BRIEF DESCRIPTION OF SPECIMENS AND TESTING PROCEDURE}

The main test series contained 19 braced portal frame subassemblages divided into 2 groups of specimens [19]: the first one comprised of angle braces welded to the main frame through a gusset plate (Fig. 6a), and the second one comprised of angle braces bolted to the main frame through a gusset plate (Fig. 6b). Each group is being differentiated by the length of the angle braces (their slenderness). Frames with bolted connections are marked as BL while those with welded connections as WL. The symbols within each group are then followed by the numbers that identify system beam length $L_{\mathrm{b}}$ in [mm].
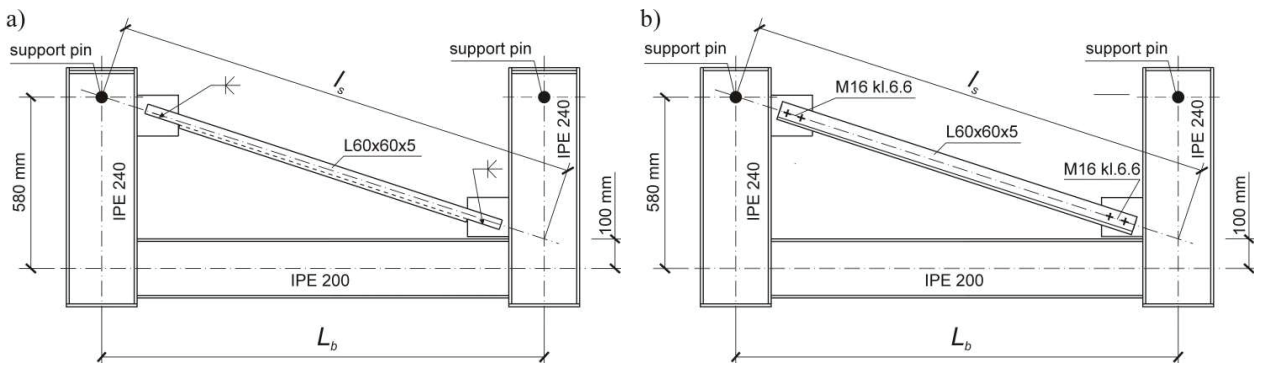

Fig. 6. Braced frame specimens tested [18]: a) frame brace with welded connections, b) frame brace with bolted connections 
Frame specimens were tested upside down. One of the supports was moveable and subjected to the horizontal travel of the jack piston while the other support was immovable and attached to the rigid stand.

\subsection{MEASUREMENTS OF THE LOAD AND DISPLACEMENT FOR THE FRAME GLOBAL RESPONSE}

All tests were conducted in a static way for a monotonically increased horizontal load (up to the level of low stiffness of the tested specimen) and then for a monotonically increased horizontal displacement in the direction and under the load application (when the limit point on the frame specimen load-deformation characteristics was presumably being reached and a descending branch of force-deformation characteristics was expected to appear). Since the brace is attached to the right frame vertically, away from the beam-to-column joint, laboratory tests showed larger local deformations of this column element in the area of the brace-to-column connection (Fig. 7a). The load cell for controlling the applied load and the corresponding displacement is shown in Fig. $7 \mathrm{~b}$. Since the brace neutral line coincides with the left vertical frame element and the line of the load application direction, there were no local deformations noticed visually.

a)

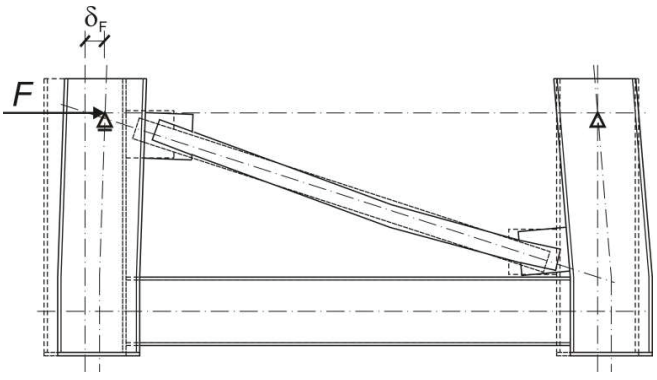

b)

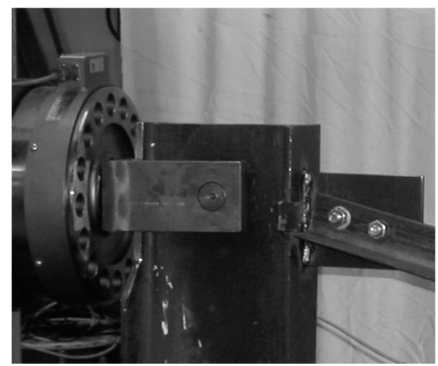

Fig. 7. Schematic presentation of the specimen's load and deformation: a) load application and deformed position, b) Load application detail (load or displacement enforced by the computer controlled program).

\subsection{EXPERIMENTAL RESULTS OF THE FRAME GLOBAL RESPONSE WITH REFERENCE TO THE EQUILIBRIUM PATH}

Frame load-displacement characteristics obtained experimentally are summarized in Fig. 8; in Fig. 8a for WL frames and in Fig. $8 \mathrm{~b}$ for BL frames. The shape of the experimentally obtained loaddisplacement frame characteristics is useful for interpreting how the buckling resistance attainment 
by the brace element influences overall frame performance. When the brace element reaches its buckling resistance (points marked by triangles), there is a change of the frame stiffness accompanied either by the reduction of the frame tangent stiffness or by the drop in the load and then the reinstatement of the positive stiffness up to the frame limit point on the equilibrium path

a)
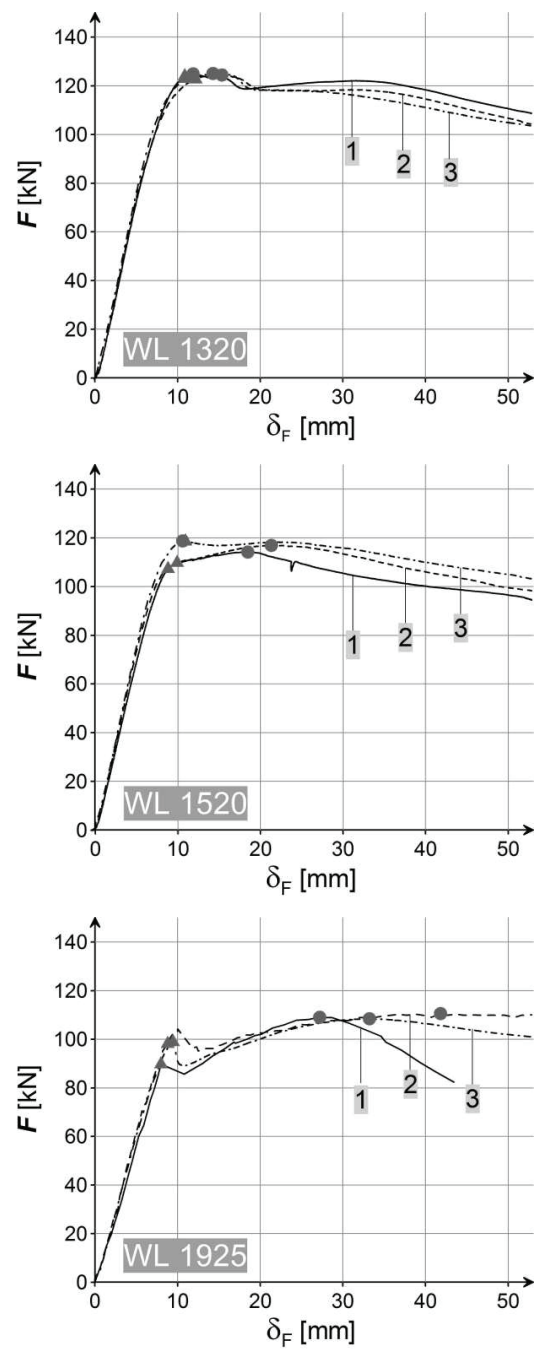

b)
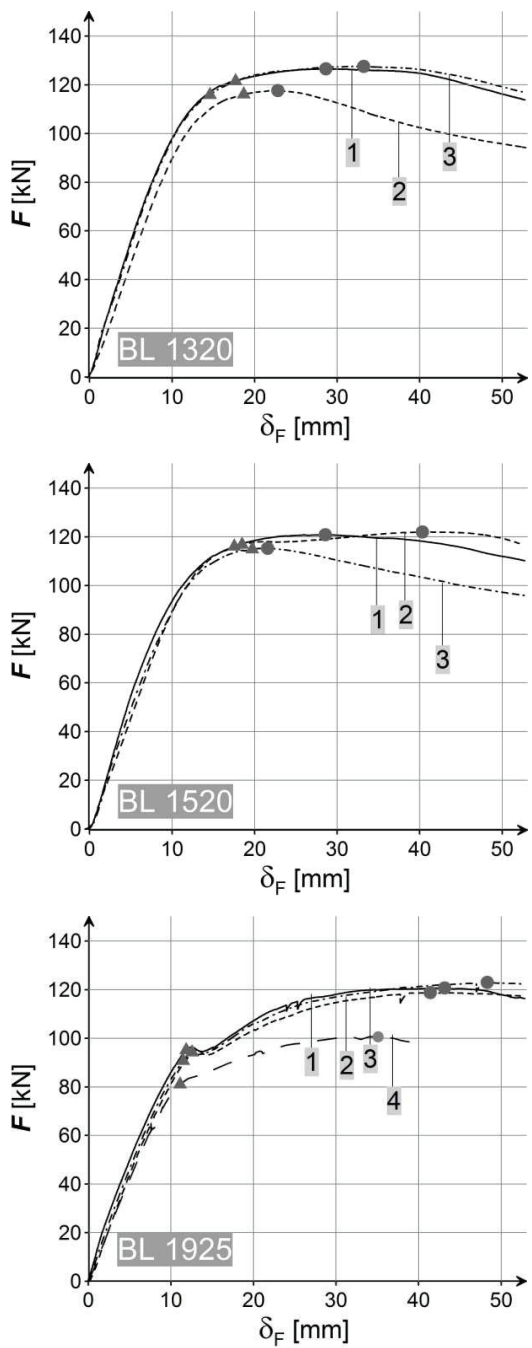

Fig. 8 Frame load-displacement characteristics (experimental global response curves): a) brace welded specimens, b) brace bolted specimens 
(points marked by circles). The brace post-limit branch of the force-deformation characteristics associated with negative stiffness results in lower frame stiffness. Lower frame stiffness is caused by the fact that the applied loads are taken up only by frame members (frame columns and the beam) while the brace does not take up load increments above the level corresponding to the brace buckling resistance. Frame members, in addition to the applied load, are subjected to actions resulting from the drop of the axial force in the brace member. This combined action of the external load and internal force softening effect leads to a faster degradation of frame stiffness. The difference between the load level corresponding to the brace buckling resistance and the frame resistance depends on brace slenderness. Generally, this difference is greater when brace slenderness is larger. It is observed that for specimens with the longest braces the difference between the load levels corresponding to the brace buckling resistance and the frame resistance is about $10 \%$ for the WL specimen and $20 \%$ for the BL specimen. The differences between the performance of WL and BL specimens disappear for specimens with the longest braces. The structure tangent of the load-displacement characteristics is smaller for BL specimens than for WL specimens. Comparing the performance of WL and BL specimens with the same brace length but with different brace connections, one may conclude that their resistance values are similar with scattering comparable to the scattering of the brace buckling resistance [19].

\section{VALIDATION OF CSD ADVANCED ANALYSIS}

\subsection{NUMERICAL MODELS OF TESTED FRAMES}

Division of the frame rafter into two line elements is used in the basic numerical model for the simulation of the frame response behaviour of frames tested experimentally, while the left column is modelled by one line element and the right column by two such elements. Fig. 9 shows this model marking the different types and sizes of the used rolled sections. Frame elements 1,4; and 5 are made of IPE 240 while elements 2 and 3 are made of IPE 200, and the bracing member is made of L60x60x5. An augmented number of elements result from notional members 6 and 7, the length of which is measured from the node of the brace-to-column neutral axis intersection points to the centre of the brace-to-gusset plate connection. They simulate the effect of member sizes by using their high stiffness and cross-section resistance values (section properties about 1000 times greater than those of IPE 240). Semi-rigid joints are marked by crossed circles. 


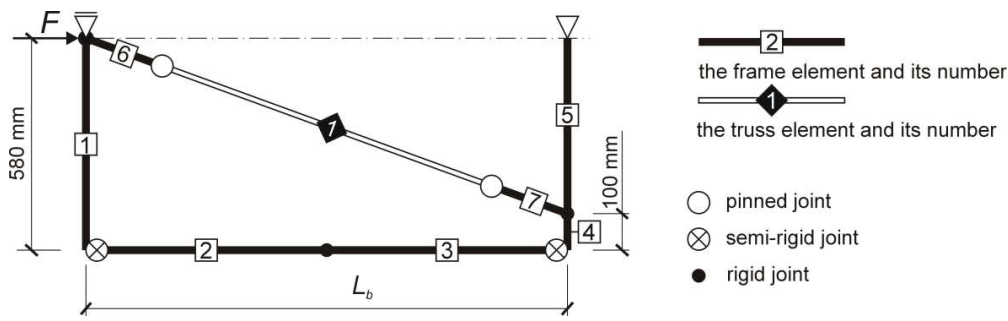

Fig. 9 Basic numerical model of tested frames identified as the simplest one

The validation process has to carefully account for all the important factors affecting the estimation of the frame equilibrium path and its peak point, defining the ultimate limit state and the nominal resistance of the frame. Those factors were proven to be the model of semi-rigid frame joints and the connection type of the brace-to-gusset plate.

The joint properties obtained by Eurocode's component method without the effect of a column cap gave a rather underestimated value of the real resistance yielding to the results of unacceptable accuracy in reference to the experimental load-displacement characteristics. The joint properties were first approximated using the Eurocode 3 component method for the verticals without the cap plate. Next, the effect of the vertical cap plates was considered as leading to a $30 \%$ higher joint resistance (the decisive component was the panel zone in shear), while the initial stiffness remained at the same level. The adopted joint characteristic was curvilinear without any rotation hardening [8]:

$$
M_{\mathrm{j}}=\left[\left(\frac{1}{S_{\mathrm{j}, \text { ini }} \phi}\right)^{-n_{\mathrm{j}}}+\left(\frac{1}{M_{\mathrm{j}, \mathrm{R}}}\right)^{-n_{\mathrm{j}}}\right]^{1 / n_{\mathrm{j}}}
$$

where:

$M_{\mathrm{j}}$ - moment at the joint, $S_{\mathrm{j}, \mathrm{ini}}$ - the initial rotational stiffness of the joint, $\phi$ - the rotation of the joint, $M_{\mathrm{j}, \mathrm{R}}-$ the joint moment resistance, $n_{\mathrm{j}}=2$ - to reproduce the behaviour up to the attainment of joint resistance similar to that predicted with the use of Eurocode 3.

A joint initial stiffness of $S_{\mathrm{j}, \text { ini }}=9995 \mathrm{kNm} / \mathrm{rad}$ was obtained fulfilling the effect of the column cap and the joint classification criterion for semi-rigid joints.

It was shown that the mesh refinement of the numerical model is not a key factor affecting frame performance. In order to prove above statement, additional mesh schemes were considered: the 
horizontal is first divided into 4 elements and next into 12 elements while the verticals are divided into 7 elements in both above-mentioned cases of the horizontal division. The initial load increment was kept constant. The obtained frame response characteristics were practically the same. The estimations of the ultimate load are very close to each other in all three discretization schemes. Greater differences in the frame response are observed when adopting different initial increments. Four initial values of the load increment are considered. The representative results are shown in Fig. 10 (for the notation, see Fig. 7) for frame specimen BL 1320 and considered as initial load increments declared in the input file. Decreasing the load increments one obtains the loaddisplacement characteristics placed lower. Differences in the ultimate load are within the range of $5 \%$ from the average. The minimal values of the frame resistance and its initial stiffness are for an initial load of about $1 / 100$ of that corresponding to the limit point on the equilibrium path.

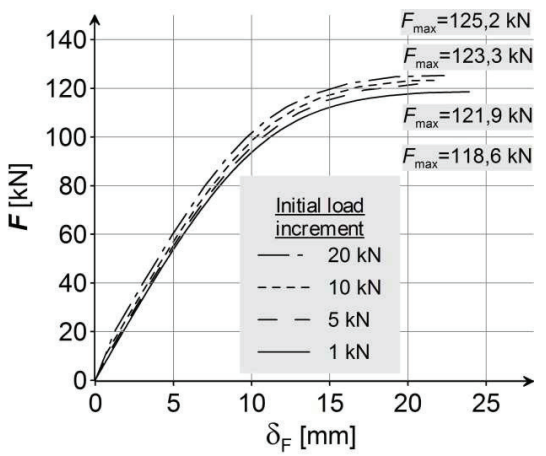

Fig 10. Load-displacement curves corresponding to different initial load increments

\subsection{FRAME GLOBAL RESPONSE EVALUATED NUMERICALLY VS EXPERIMENTALLY OBTAINED RESULTS}

Validation of the CSD advanced analysis was presented using experimental results alongside those from ECIDA numerical simulations for the basic numerical model and for an initial load increment of about 1/100 of the load obtained experimentally at the limit point on the frame equilibrium path. Accuracy predictions were evaluated by comparing the brace force-deformation characteristics obtained numerically to those represented by closed form analytical solutions as well as by comparing the degradation functions for both frame member 3 in Fig. 9 and brace member 1 in Fig. 9. Frame member 3, connecting nodes: left "i" and right " $\mathrm{k}$ ", is chosen because its end "k" is characterized by the lowest values of the stiffness degradation functions. 
Figs. 11-13 show experimental vs. numerical results for the overall frame response as well as numerical vs. analytical results for the local brace response for frames with symbols 1320, 1520, and 1925, respectively. Characteristics presented in each of the a) figures deal with WL frames, while in b) the figures deal with BL frames. From above, both a) and b) represent the curves:

1. Experimental and numerical frame load-displacement characteristics $F-\delta_{\mathrm{F}}$ (where $F$ is the applied load and $\delta_{\mathrm{F}}$ is the displacement of the vertical member in the horizontal direction consistent with the direction of applied load. The envelope of experimental results is coloured gray.

2. Numerical stiffness degradation functions $\eta$ for selected frame members, namely $\eta_{\mathrm{Nf}}, \eta_{\mathrm{Mi}}, \eta_{\mathrm{Mk}}$ and for truss member $\eta_{\mathrm{Nt}}$.

3. Numerical and analytical dimensionless force-deformation characteristics $\sigma / f_{\mathrm{y}}$ of the brace member.

4. Numerical and analytical axial stiffness degradation functions $\eta_{\mathrm{Nt}}$ for the brace member.

Symbols used for discrete points are identical to those used in Fig. 8; circles identify the ultimate limit state of braced frames, triangles - the load level corresponding to the attainment of brace member buckling resistance. The black lines represent the numerically obtained equilibrium path traced up to the limit point, the gray areas represent the envelope of experimentally obtained equilibrium paths, the black numbers on a gray background - numerical results, and, finally, white numbers on the same background - experimentally obtained results corresponding to the upperbound and lower-bound (maxima and minima of the ultimate limit load).

It is clear that the numerically obtained curves representing degradation functions $\eta_{\mathrm{Nf}}$ and $\eta_{\mathrm{Nt}}$ start from two different levels. The former refers to a frame member that is stocky enough so that its initial stiffness parameter $E_{0} / E$ is practically equal to unity. Contrarily, the initial stiffness of WL and BL bracing members may differ substantially (see Fig. 4).

For BL type frames, equilibrium paths obtained numerically through the use of CSD advanced analysis are in a good agreement with the experimental ones with regard to both frame initial stiffness and resistance. The frame ultimate limit state is associated with the overpass of the deformation level associated with the buckling resistance of a brace member, and displaced frame configuration indicates that there are rather large plastic deformations within the structural members. As a result, the stiffness degradation functions of frame elements at the frame ultimate limit state are of low positive values, and for bracing members even attain negative values.

Analogically, equilibrium paths obtained numerically for WL type frames through the use of CSD advanced analysis are in a good agreement with the experimental ones except for the resistance of specimen WL1925. 
a)
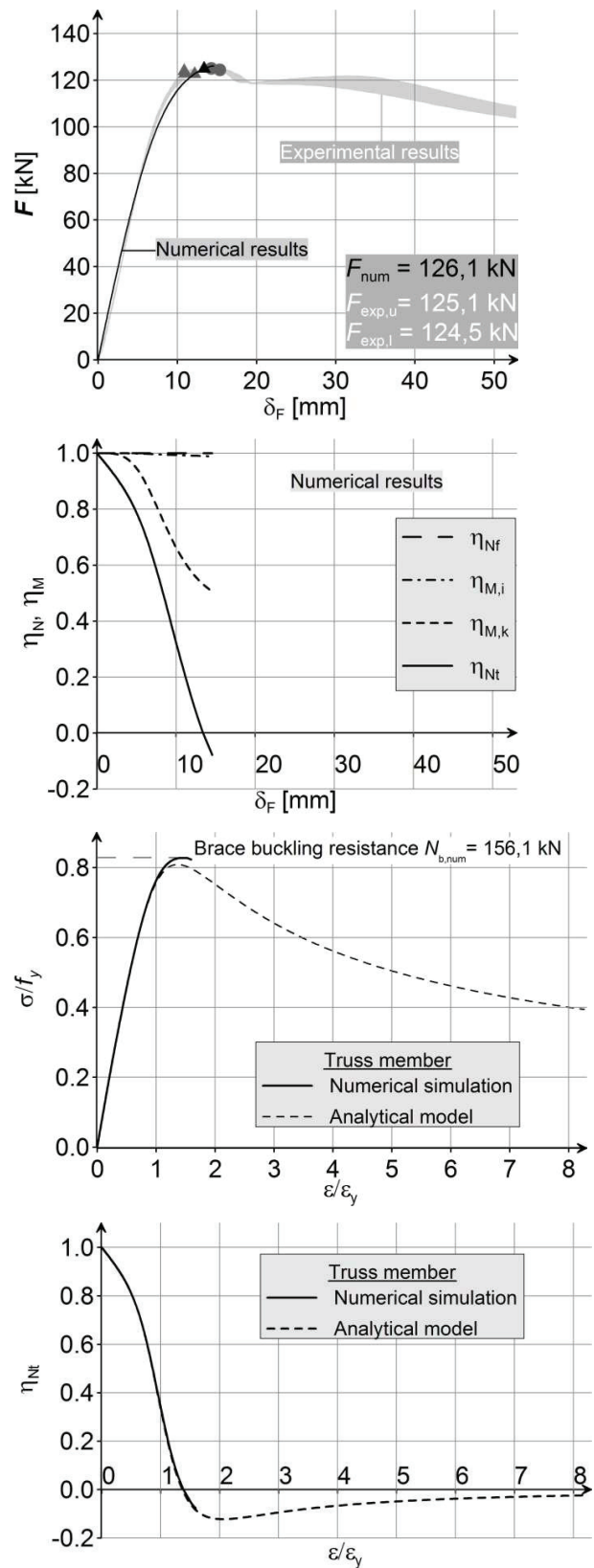

b)
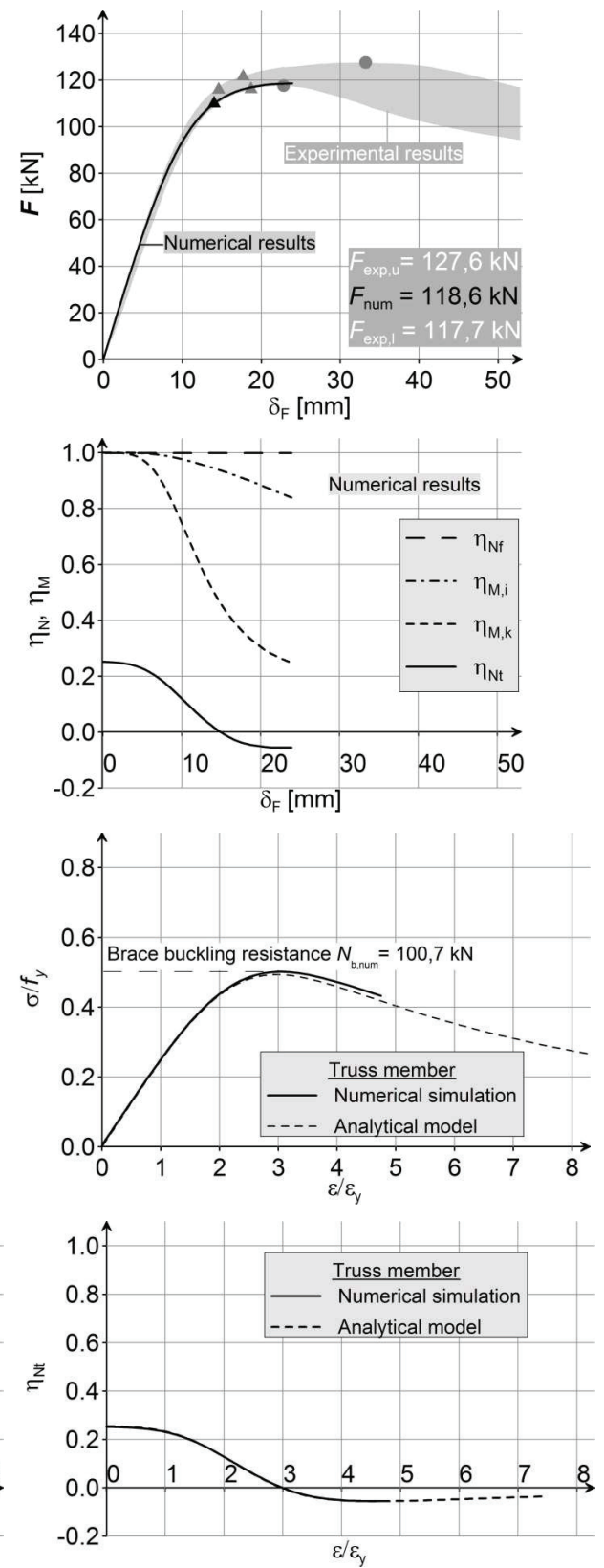

Fig. 11 Experimental vs. numerical and numerical vs. analytical results for the frame: 
a) WL 1320, b) BL 1320

a) b)
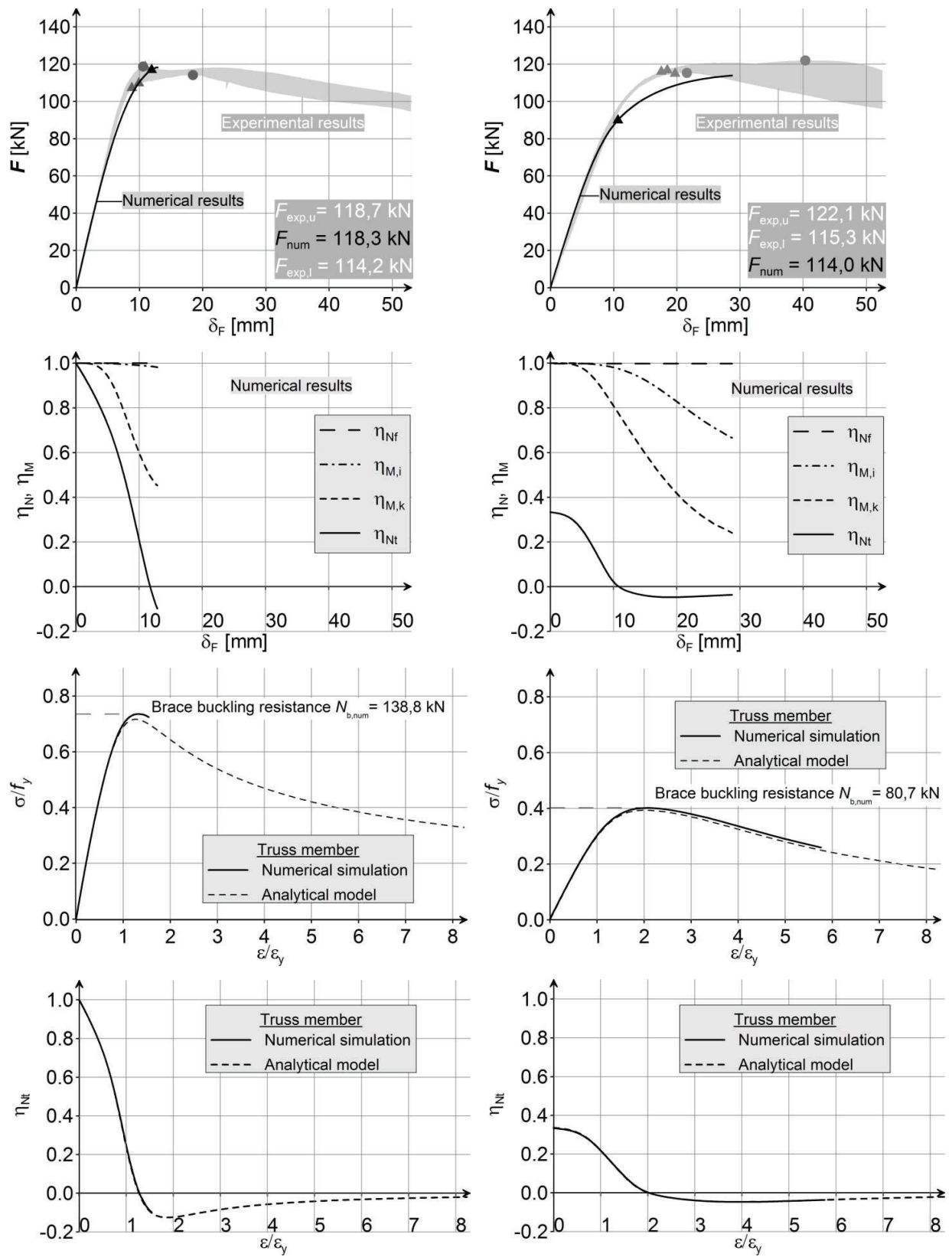
Fig. 12 Experimental vs. numerical and numerical vs. analytical results for the frame:

a) WL 1520, b) BL 1520

a)
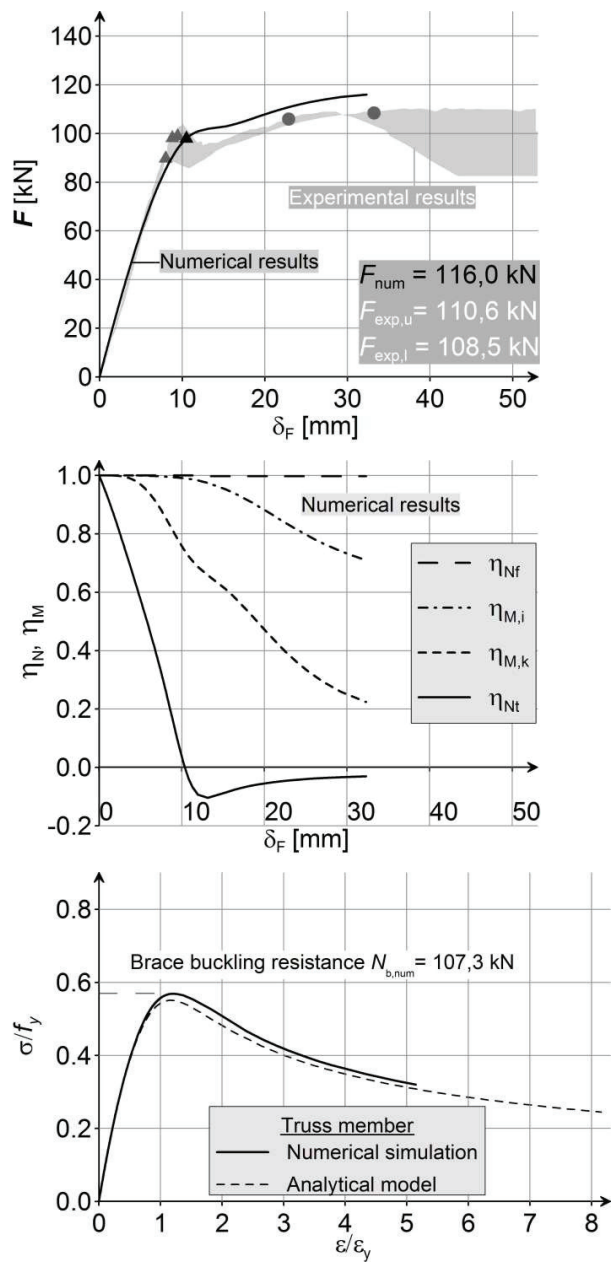

b)
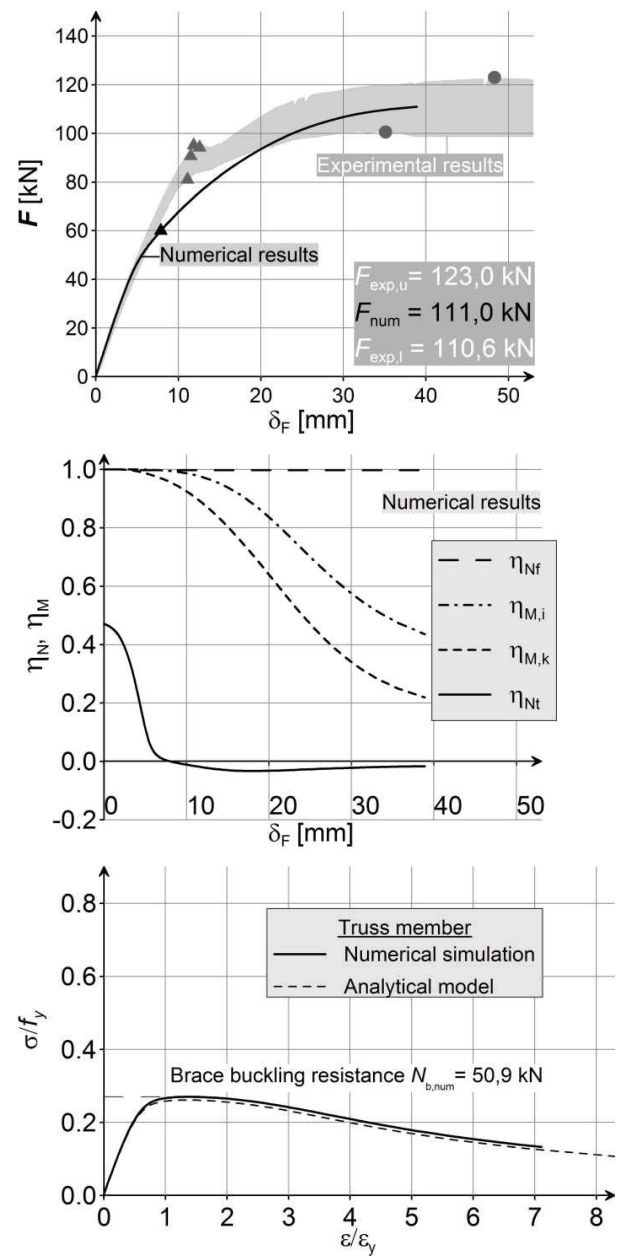

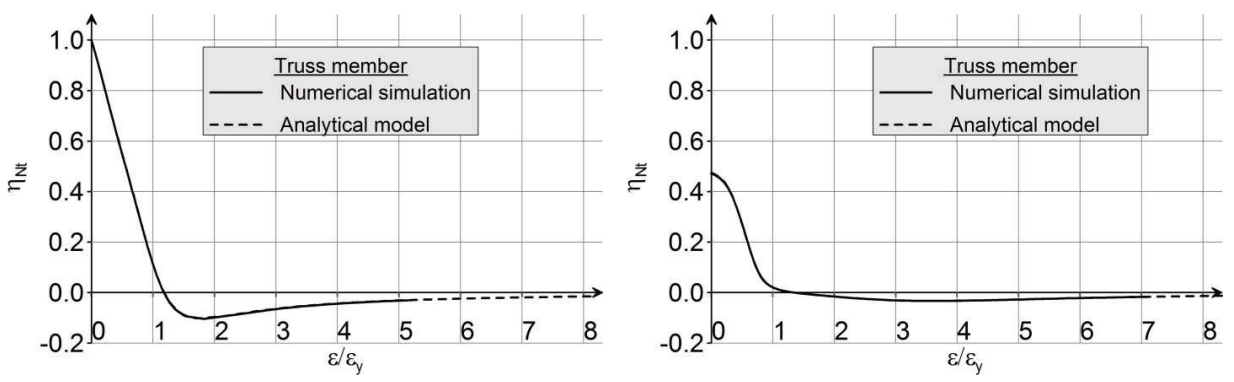

Fig. 13 Experimental vs. numerical and numerical vs. analytical results for the frame:

a) WL 1925, b) BL 1925

Welded brace connections improve frame stiffness but reduce ductility. As a result, displacements of WL frames during resistance are lesser than those referring to BL frames of the same brace length. The frame's ultimate limit state is associated with the overpass of the deformation level at the buckling resistance point of a brace member. The stiffness reduction for frame members is generally within the similar range or of greater values for WL frames than for the BL frames (see element 3 at ends " $i$ " and " $k$ "). Contrarily, stiffness reduction for truss members is of greater values for BL frames than for the corresponding WL frames.

\section{CONCLUDING REMARKS}

The basic concept of the CSD analysis presented in this study remains similar to that of the advanced RPH analysis presented in [8]. The differences arise from the following reasoning:

1. Assembling a structure from imperfect elements and introducing the initial stress state as a result of the execution process leads to a situation where permanent local plastic deformations and a reduction in stiffness begin taking place almost immediately at the moment of service load application.

2. There is a need for consistency in the evaluation of structure stiffness reduction in order to conform to current recommendations of Eurocode 3 [21].

There are important attributes of CSD advanced analysis which give this method advantages over the RPH method, namely:

1. In the CSD method, modelling of the stiffness degradation process starts at the beginning of the load application process, therefore this method most closely resembles situations which take place in real structures. 
2. Modelling of the stiffness degradation process in cases of zero bending moments with the axial force state existing only in frame elements coincides with the reproduction of the results of the Shanley theory of inelastic stability.

3. Accounting for the axial force softening effect of brace members having an important influence on the axial force redistribution process and the limit point attainment in statically indeterminate trusswork or braced framework.

The above remarks allowed for improvements made in advanced CSD analysis when compared with that of the RPH concept of analysis presented in [8], for both frame elements and truss elements of structural load-bearing systems. The developed version of advanced analysis and its implementation into the ECIDA computer program were positively validated using the experimental data of laboratory investigations carried out at the Warsaw University of Technology by the author. It is therefore possible to use the validated CSD advanced analysis as the basis for the development of computer software for the direct limit states design of new steel frameworks or for the resistance and serviceability assessment of existing structures.

\section{ACKNOWLEDGEMENTS}

Experimental work was conducted at the Structures Laboratory of the Metal Structures Division of the Faculty of Civil Engineering of the Warsaw University of Technology. The assistance provided by laboratory staff members under the leadership of Mr. Jan Witkowski and Mr. Włodzimierz Sotomski is highly appreciated.

\section{REFERENCES}

1. W. S. King, D. W. White, W. F. Chen, "Second-order inelastic analysis methods for steel-frame design", Journal of Structural Engineering, 118 (2), 408-428, 1992.

2. ECCS, "Ultimate Limit State Calculation of Sway Frames with Rigid Joints", European Convention for Constructional Steelwork, Technical Committee 8 - Structural Stability, Technical Working Group 8.2, 1984.

3. D. W. White, W. F. Chen, Plastic Hinge based Methods for Advanced Analysis and Design of Steel Frames An Assessment of the State of the Art, Structural Stability Research Council, Lehigh University, Bethlehem, PA, USA, 1993.

4. M. R. Attalla, G. G. Deierlein, W. McGuire, "Spread of plasticity: Quasi-plastic-hinge approach", Journal of Structural Engineering, 120 (8), 2451-2473, 1994.

5. C. Díaz, P. Martí, M. Victoria, O. M. Querin, "Review on the modelling of joint behaviour in steel frames", Journal of Constructional Steel Research, 67 (5), 741-758, 2011.

6. W. F. Chen, E. M. Lui, "Effects of joint flexibility on the behavior of steel frames", Computers \& Structures, 26(5), 719-732, 1987.

7. Y. Goto, W. F. Chen, "On the computer-based design analysis for the flexibly jointed frames", Journal of Constructional Steel Research, 8, 203-231, 1987.

8. W. F. Chen, S. E.Kim, "LRFD Steel Design using Advanced Analysis", CRC Press, Boca Raton, 1997. 
9. M. A. Giżejowski, Computational models of steel plane frames with semi-rigid joints, Series: Inżynieria Lądowa, vol. 136, Oficyna Wydawnicza PW, Warszawa, 2000 [in Polish].

10. M. A. Gizejowski, A. M. Barszcz, "Advanced analysis of inelastic steel truss and frame structures - a unified approach", Proceedings of SDSS 2006 - International Colloquium on Stability and Ductility of Steel Structures (Eds. D. Camotim, N. Silvestre, P. Dinks), IST Press Lisbon, 1, 431-438, 2006.

11. M. A. Gizejowski, A. M. Barszcz, C. J. Branicki, H. C. Uzoegbo, "Review of analysis methods for inelastic design of steel semi-continuous frames", Journal of Constructional Steel Research, 62, 81-92, 2006.

12. M. Giżejowski, A. Barszcz, A. Kozłowski, L. Ślęczka, "Current practice and future development in modelling, analysis and design of steel semi-continuous frames", Archives of Civil Engineering. 54, 73-128, 2008.

13. H. Gorgun, "Geometrically nonlinear analysis of plane frames composed of flexibly connected members", Structural Engineering and Mechanics, International Journal, 45 (3), 277-309, 2013.

14. H. R. Valipour, M. A. Bradford, "Nonlinear P-D analysis of steel frames with semi-rigid connections", Steel and Composite Structures, 14 (1), 1-20, 2013.

15. P. C. Nguyen, N. T. N. Doan, C. Ngo-Huu, S. E. Kim, "Nonlinear inelastic response history analysis of steel frame structures using plastic-zone method", Thin-Walled Structures, 85, 220-233, 2014.

16. P. C. Nguyen, S. E. Kim, "Advanced analysis for planar steel frames with semi-rigid connections using plasticzone method", Steel and Composite Structures, 21 (5), 1121-1144, 2016.

17. S. L. Chan, Y. P. Liu, S. W. Liu, "A New Codified Design Theory of Second-order Direct Analysis for Steel and Composite Structures - From Research to Practice", Structures, 9, 105-111, 2017.

18. A. M. Barszcz, "Experimentally assisted modelling of the behaviour of steel angle brace", Archives of Civil Engineering, LX (1), pp. 3-39, 2014.

19. A.M. Barszcz, "Experimental investigations of braced frame system", Inżynieria i Budownictwo, 7, 380-384, 2010 [in Polish]

20. EN 1993-1-1, Eurocode 3: Design of steel structures. Part 1-1: General rules and rules for buildings,, Brussels: CEN, 2005.

21. A.M. Barszcz, M.A. Gizejowski, "An Equivalent Stiffness Approach for Modeling the Behavior of Compression Members According to Eurocode 3", Journal of Constructional Steel Research, 63 (1), 55-70, 2007.

22. M. Kucukler, L. Gardner, L. Macorini, "A stiffness reduction method for the design of structural steel elements", Engineering Structures 73, 72-84, 2014

23. M. Kucukler, L. Gardner, L. Macorini, "Development and assessment of a practical stiffness reduction method for the in-plane design of steel frames", Journal of Constructional Steel Research, 126, 187-200, 2016.

24. J. Y. Liew, W. F. Chen, "Second-order plastic hinge analysis of frames" in "Adavanced analysis of steel frames: Theory, software and applications", (Eds. W.F. Chen \& S. Toma). CRC Press: Boca Raton, 139-194, 1994.

25. M. A. Gizejowski, J. P. Papangelis, H. C. Parameswar, "Stability design of semi-continuous steel frame structures", Journal of Constructional Steel Research, 46 (1-3), 1998 [full text in e-version on attached CD]. 


\section{LIST OF FIGURES:}

Fig. 1. Illustration of the effect of axial force on frame element stiffness: a) Hypothetical stress-strain relationship, b) Degradation function $\eta_{\mathrm{Nf}}$ referring to the relative axial force, c) Degradation function $\eta_{\mathrm{Nf}}$ referring to the relative axial strain

Rys. 1. Ilustracja wpływu siły osiowej na sztywność zginania: a) Hipotetyczna zależność naprężenieodkształcenie, b) Funkcja degradacji $\eta_{\mathrm{Nf}}$ odniesiona do względnej siły osiowej, c) Funkcja degradacji $\eta_{\mathrm{Nf}}$ odniesiona do względnego odkształcenia osiowego

Fig. 2. Illustration of stiffness degradation modelling in CSD advanced analysis

Rys. 2. Ilustracja modelowania degradacji sztywności w zaawansowanej analizie CSD

Fig. 3. Conceptual sketch of stiffness degradation function $\eta_{\mathrm{Nt}}$ for truss bracing: a) Hypothetical stress-strain relationship; b) Degradation function of the axial stiffness expressed with regard to the axial force, c) Degradation function of the axial stiffness expressed with regard to the axial deformation

Rys. 3. Koncepcyjny szkic funkcji degradacji sztywności $\eta_{\mathrm{Nt}}$ dla pręta stężenia; a) Hipotetyczna zależność naprężenie-odkształcenie osiowe, b) Funkcja degradacji sztywności wyrażona w odniesieniu do siły osiowej, c) Funkcja degradacji sztywności wyrażona w odniesieniu do odkształcenia.

Fig. 4. Illustration of stiffness degradation function $\eta_{\mathrm{Nt}}$ a) Hypothetical stress-strain relationship; b) Stiffness degradation function in terms of axial deformation, c) Stiffness degradation function in terms of axial force Rys. 4. Ilustracja funkcji degradacji sztywności $\eta_{\mathrm{Nt}}$ : a) Hipotetyczny związek naprężenie-odkształcenie osiowe, b) Funkcja degradacji sztywności w odniesieniu do odkształceń osiowych, c) Funkcja degradacji sztywności w odniesieniu do siły osiowej

Fig. 5 Flow chart of ECIDA program execution

\section{Rys. 5. Schemat działania programu ECIDA}

Fig. 6. Braced frame specimens tested [18]: a) brace with welded connections, b) brace with bolted connections

Rys. 6. Badane ramy stężone [18]: a) stężenie $\mathrm{z}$ połączeniem spawanym, b) stężenie $\mathrm{z}$ połączeniem śrubowym

Fig. 7. Schematic presentation of the specimen's load and deformation: a) load application and deformed position, b) Cell for load and piston travel control (enforced by the computer controlled signal according to the prescribed monotonic load program).

Rys. 7. Schematyczne przedstawienie obciążenia i odkształcenia elementu doświadczalnego: a) obciążenie i odkształceniem ramy, b) czujnik do pomiaru siły obciążającej ramę i sterowania przemieszczaniem tłoka (wymuszone przez sygnał sterowany komputerowo zgodnie $\mathrm{z}$ przewidzianym programem obciążenia monotonicznego).

Fig. 8 Frame load-displacement characteristics (experimental global response curves): a) brace welded specimens, b) brace bolted specimens 
Rys. 8. Charakterystyka obciążenie-przemieszczenie ramy (doświadczalne globalne krzywe odpowiedzi): a) przyspawane pręty stężenia, b) przyśrubowane pręty stężenia

Fig. 9 Basic numerical model of tested frames identified as one element per frame member

Rys. 9. Podstawowy model numeryczny badanych ram identyfikowany jako jeden element na element ramowy

Fig 10. Load-displacement curves corresponding to different initial load increment

Rys. 10. Krzywe obciążenia i przemieszczenia odpowiadające różnym początkowym przyrostom obciążenia

Fig. 11 Experimental vs. numerical and numerical vs. analytical results for the frame: a) WL 1925, b) BL 1925

Rys. 11. Porównanie wyników doświadczalnych z numerycznymi i numerycznych z analitycznymi dla ram: a) WL 1320, b) BL 1320 .

Fig. 12 Experimental vs. numerical and numerical vs. analytical results for the frame: a) WL 1520, b) BL 1520

Rys. 12. Porównanie wyników doświadczalnych z numerycznymi i numerycznych z analitycznymi dla ram a) WL 1520, b) BL 1520

Fig. 13 Experimental vs. numerical and numerical vs. analytical results for the frame: a) WL 1925, b) BL 1925

Rys. 13. Porównanie wyników doświadczalnych z numerycznymi i numerycznych z analitycznymi dla ram:

a) WL 1925 , b) BL 1925

Received 02.02.2018

Revised 29.05.2018 


\title{
WALIDACJA ZAAWANSOWANEJ ANALIZY CSD RAM STĘŻONYCH Z WYKORZYSTANIEM BADAŃ DOŚWIADCZALNYCH PODZESPOLÓW RAMOWYCH
}

\author{
Keywords: rama stalowa, rama stężona, stężenie z kątownika, zachowanie pokrytyczne, analiza zaawansowana \\ CSD, walidacja modelu obliczeniowego
}

\section{STRESZCZENIE:}

Artykuł dotyczy analizy zaawansowanej - Continuous Stiffness Degradation (CSD) stalowych stężonych układów szkieletowych Pionowe stężenia ram składają się z elementów kratownicowych połączonych z elementami ramowymi. Technika modelowania oparta jest na koncepcji stopniowej degradacji sztywności elementów ramy i kratownicy. Nowatorstwo podejścia przedstawionego w niniejszym artykule związane jest z wprowadzeniem odpowiedzi elementu stężającego w całym zakresie jego zachowania przy rozciąganiu i ściskaniu, w tym w zakresie po osiągnięciu nośności na wyboczenie. Walidacja proponowanej zaawansowanej analizy jest przeprowadzana dla podsystemu ramowego składającego się $\mathrm{z}$ dwuteowników stanowiących ramę podstawową i jednego pręta stężającego z kątownika walcowanego, dla którego walidacja zależności siła-przemieszczenie została przedstawiona we wcześniejszej publikacji autora, cytowanej w artykule.

Przedstawiono krótki przegląd propozycji analizy konstrukcji ram stalowych z uzasadnieniem wyboru zaawansowanej analizy CSD i określeniem jej odmienności w stosunku do zaawansowanej analizy udoskonalonego przegubu plastycznego (RPH). Zamieszczono wzory analityczne do wyznaczania współczynników redukcji sztywności i na wykresach pokazano przebieg ich zmienności przy obciążeniu momentem zginającym i siłą osiową w przypadku elementów ramowych, a w przypadku elementów kratowych tylko siła osiową.

Krótko omówiono program badań doświadczalnych stężonych podsystemów ram portalowych, który przedstawiany był szczegółowo we wcześniejszych publikacjach. Zamieszczono wyniki badań doświadczalnych w postaci ścieżek równowagi ram badanych doświadczalnie $F-\delta_{\mathrm{F}}$, z zaznaczonymi punktami granicznymi i charakterystycznymi, za które uznano osiągnięcie nośności wyboczeniowej przez pręt stężenia ramy. Wyniki te wykorzystano do walidacji opracowanego modelu obliczeniowego ram stężonych. Porównano przebieg ścieżek równowagi w zakresie sztywności i nośności układów oraz pokazano przebieg degradacji sztywności pręta stężenia i najbardziej obciążonego elementu rygla ramy. Porównano otrzymane analitycznie i numerycznie przebiegi zależności siła-odkształcenie oraz współczynnik redukcji sztywności w funkcji odkształcenia osiowego pręta stężenia. Wnioski sformułowano wodniesieniu do zastosowania zwalidowanego modelu w bezpośrednim projektowaniu stężonych stalowych konstrukcji szkieletowych. 